\title{
Lectures
}

\section{VICARIOUS LIABILITY IN TORTS: THE SEX EXCEPTION}

\author{
Martha Chamallas*
}

\section{INTRODUCTION}

In recent years, trusted institutions - from the Catholic Church, to the Boy Scouts, to Penn State, and the BBC-have become embroiled in scandals involving allegations of widespread sexual abuse of vulnerable children. Behind these scandals is not only a story of abusive individuals who hurt large numbers of victims but also a story of widespread institutional failure. The highly publicized cases against the Catholic Church, for example, challenged an earlier understanding of the nature and dimension of the sexual abuse problem. In particular, we learned that the problem was widespread. Professor Timothy Lytton, a prominent legal commentator on the topic, for example, recounts the "astonishing fact" that over 13,000 children and adolescents have been abused by Catholic priests since 1950.1 Sadly, we also discovered that many church officials were responsible for exacerbating the problem by minimizing or denying the suffering of victims and by covering up the problem and transferring scores of offending priests to other parishes. ${ }^{2}$

The story of widespread abuse and institutional failure is now so familiar it is hard to keep track of even the high-profile cases. You may recall that, in 2012, the once secret, so-called "perversion files" of the Boys Scouts of America were made public, detailing accusations of sexual abuse by over 1200 scout leaders from 1965 to $1985 .^{3}$ In that same year, assistant coach Jerry Sandusky at Penn State was found guilty of forty-five counts of abusing young boys under the aegis of a charity he

\footnotetext{
* Robert J. Lynn Chair in Law, Moritz College of Law, The Ohio State University. I am grateful to the many faculty, students, and audience members at Valparaiso University Law School who offered valuable comments at the 2013 Monsanto Lecture in Tort Law and Jurisprudence and helped me develop and refine the ideas in this Article. Many thanks as well to Sanya Shah, Daniella Vespoli, and Ina Avalon, my terrific research assistants at Ohio State.

1 TIMOTHY D. LytTON, Holding Bishops ACCOUNTABLE: How LaWSUITS HelPED THE CATHOLIC CHURCH CONFRONT ClERGY SEXUAL ABUSE 190 (2008).

2 Marci A. Hamilton, The Waterloo for the So-Called Church Autonomy Theory: Widespread Clergy Abuse and Institutional Cover-Up, 29 CARDOZO L. REv. 225, 227-28 (2007).

3 Kirk Johnson, Newly Released Boy Scout Files Give Glimpse into 20 Years of Sexual Abuse, N.Y. TIMES, Oct. 19, 2012, at A20, available at 2012 WLNR 22167986.
} 
formed to help troubled youths. ${ }^{4}$ Outside the United States, the venerable $\mathrm{BBC}$ was thrown into turmoil when it was revealed that Jimmy Savile, a famous host of TV shows for kids and teens, had molested numerous girls and boys, many of whom were hospitalized at the time with serious illnesses. ${ }^{5}$ These are just a few of the most visible cases $^{6}$ - the case reporters are filled with more prosaic sexual abuse cases brought by children and adults against group homes, schools, mental health facilities, hospitals, and other institutional settings.

Most people likely assume that these institutions are legally responsible for the damage caused by such abuse, provided one can prove that the abuse did indeed take place. Although they may never have heard of the term "vicarious liability" or "respondeat superior," 7 there is a commonly-held notion that a business or enterprise should pay for the damage done by its employees. As Patrick Atiyah expounded in the late 1960s, "the man in the street" thinks of a corporation with its officers and employees as an identifiable unity, as in "[ $t]$ hey ought to

4 Joe Drape, Sandusky Guilty of Sexual Abuse of 10 Young Boys, N.Y. TIMES, June 23, 2012, at A1, available at 2012 WLNR 13114287.

$5 \quad$ Michael Holden, British TV Host Savile Sexually Abused Hundreds, Report Says, WASH. POST, Jan. 12, 2013, at A14, available at 2013 WLNR 858475.

6 For other visible controversies see generally Amos Kamil, Great Is the Truth, and It Prevails, N.Y. TIMES, June 10, 2012, at MM26, available at http://www.nytimes.com/ 2012/06/10/magazine/ the-horace-mann-schools-secret-history-of-sexual-abuse.html?page wanted=all (discussing sexual abuse at Horace Mann, an elite private school in New York City); Juliet Macur \& Nate Schweber, Rape Case Unfolds on Web and Splits City, N.Y. TiMES, Dec. 17, 2012, at D1, available at http://www.nytimes.com/2012/12/17/sports/high-school -football-rape-case-unfolds-online-and-divides-steubenville-ohio.html (discussing sexual assault and rape by student athletes); Sharon Otterman \& Ray Rivera, Ultra-Orthodox Shun Their Own for Reporting Child Sex Abuse, N.Y. TIMES, May 10, 2012, at A1, available at http://www.nytimes.com/2012/05/10/nyregion/ultra-orthodox-jews-shun-their-own-for -reporting-child-sexual-abuse.html (discussing a close-knit religious community that shuns reporters of sex abuse); Richard Pérez-Peña, \& Ian Lovett, 2 More Colleges Accused of Mishandling Assaults, N.Y. TIMES, Apr. 19, 2013, at A14, available at http://www.nytimes.com/2013/04/19/education/swarthmore-and-occidental-collegesare-accused-of-mishandling -sexual-assault-cases.html?_r=0 (discussing the mishandling of sexual assaults on college campuses); Karisa King, In Cases of Military Sexual Assault, Victims Are Victimized Twice, Bus. INSIDER (May 25, 2013, 3:29 PM), $\mathrm{http}: / /$ www.businessinsider.com/in-cases-of-military-sexual-assault-victims-arevictimized-twice-2013-5 (discussing the military's failed handling of sexual assault cases); Michael O'Keeffe, Poly Prep Settles Lawsuit Claiming Football Coach Phil Foglietta Sexually Abused Hundreds of Boys, N.Y. DaILY NEws (Dec. 26, 2012, 6:53 PM), http://www.ny dailynews.com/sports/i-team/poly-prep-settles-sex-abuse-suit-article-1.1227827?pgno=1 (discussing a football coach who sexually abused hundreds of boys over a period of twenty-five years).

7 "Respondeat superior" is Latin for "[l]et the master answer." WILLIAM R. BUCKLEY \& CATHY J. OKRENT, TORTS AND PERSONAL INJURY LAW 74 (3d ed. 2004). 
pay." 8 This intuitive identification of a corporate entity with its employees makes it seem fair to impose liability upon employers for the torts of its employees, at least when those employees commit torts while on the job. Although scholars have not resolved the debate over whether the doctrine of vicarious liability truly has ancient roots, 9 there is no doubt that the doctrine is a bedrock principle of contemporary tort law. Citing the influence of worker's compensation and the Federal Tort Claims Act, Dan Dobbs goes so far as to say that "our culture now often believes that fairness requires the business enterprise, not the servant to pay."10 In a similar vein, Gary Schwartz began his influential article on vicarious liability by stating that "there is now a consensus... that vicarious liability is an essential element in the tort system. Any idea of repealing vicarious liability would seem to us preposterous, inconceivable."11

However, when it comes to sexual abuse and exploitation cases, tort law gives no crisp answer to the question of whether a business is vicariously liable for the sexual torts committed by its employees. Instead, the cases are conflicting and confusing, with a decided tendency to rule against vicarious liability in the sexual misconduct context. This reluctance to impose vicarious liability persists even though there is often a pressing need for compensation in this context. One Canadian writer has noted that "[v]ulnerable victims, especially potential incest or child sexual exploitation victims, are obviously poor candidates for insurance or other self-protection. The people who might advise them about the risks - their parents, priests, coaches, teachers and so on-are

8 P.S. ATIYAH, VICARIOUS LIABILTTY IN THE LAW OF TORTS 20 (1967).

9 Oliver Wendell Holmes, for example, thought that the doctrine originated in Roman law and was associated with a master's liability for the acts of his slaves. See OLIVER WENDELL HOLMES, JR., THE COMMON LAW 15-17 (1881) (discussing the influence of Roman law on the common law vicarious liability doctrine). The rule originally required the master to surrender the slave to the victim and then subsequently allowed the master to buy off the victim and keep the slave. Id. at 15. Atiyah, however, claimed that the Holmesian theory found little support among historians. ATTYAH, supra note 8, at 19. Another theory posits that vicarious liability is an "indulgence" accorded to employers representing the price of permitting employers to secure others to do their work for them. Id. See generally Gary T. Schwartz, The Hidden and Fundamental Issue of Employer Vicarious Liability, 69 S. CAL. L. REv. 1739, 1746 (1996) (rejecting the view that vicarious liability is "ancient"); Rochelle Rubin Weber, Note, "Scope of Employment" Redefined: Holding Employers Vicariously Liable for Sexual Assaults Committed by Their Employees, 76 MiNN. L. REV. 1513, 1515-17 (1992) (discussing historical development of respondeat superior).

10 2 DAN B. DOBBS, THE LAW OF TORTS § 333, at 907 (2001).

11 Schwartz, supra note 9, at 1745; see ATIYAH, supra note 8, at 12 ("Vicarious liability is one of the most firmly established legal principles throughout the common law world."). 
too often the very people who perpetrate the abuse."12 Absent vicarious liability, sexual abuse victims are forced to seek compensation from the perpetrators themselves, ${ }^{13}$ a notoriously unreliable source of funds given the fact that many offenders end up in jail and few individuals are able to satisfy large tort judgments in the absence of insurance. Of course, some victims will be able to establish that employers were independently negligent for failing to screen, train, or monitor the offending employee. Such a direct negligence claim, however, is far more difficult and costly to prove and leaves many sexual abuse victims effectively without a remedy.

Beginning law students quickly learn that employers are automatically liable for torts committed by their employees "in the course and scope of their employment." To trigger vicarious liability, a plaintiff need not prove that the employee committed a tort at the specific direction of the master. ${ }^{14}$ Rather, the employer is liable for all the servant's negligent acts, even though the master did not command them or could not foresee them in any specific way. ${ }^{15}$ In fact, employers may be liable even when the employee violates a specific work rule. ${ }^{16}$ There is vicarious liability, for example, when an employee drives over the speed limit while making deliveries in the company's truck, even if that employee has been specifically warned not to speed.

In sexual abuse cases, however, the "course and scope of employment" test has been applied much more restrictively. Courts are far less likely to hold employers vicariously liable for sexual abuse committed by employees, even as compared to other cases of non-sexual, intentional torts. ${ }^{17}$ This means that, in sexual misconduct cases, courts

12 Bruce Feldthusen, Vicarious Liability for Sexual Torts, in TORTS TOMORROW: A TRIBUTE TO JOHN FLEMING 221, 225 (Nicholas J. Mullany \& Allen M. Linden eds., 1998); see Julie M. Arnold, Note, "Divine" Justice and the Lack of Secular Intervention: Abrogating the ClergyCommunicant Privilege in Mandatory Reporting Statutes to Combat Child Sexual Abuse, 42 VAL. U. L REV. 849, 889-98 (2008) (advocating the abrogation of the clergy-communicant privilege in mandatory state reporting statutes to combat child abuse within the church).

13 In rare cases, sexual abuse victims may be able to secure an award through workers' compensation, provided that they are also employees of the defendant and their injury is compensable under the state workers' compensation scheme. See, e.g., Cremen v. Harrah's Marina Hotel Casino, 680 F. Supp. 150, 154 (D.N.J. 1988) (finding that a sexual abuse victim was entitled to workers' compensation).

142 DOBBS, supra note 10, § 334, at 907; RICHARD A. EPSTEIN \& CATHARINE M. SHARKEY, CASES AND MATERIALS ON TORTS 694 (10th ed. 2012) ("[F]rom 1700 on, vicarious liability turned on whether the tort arose out of the servant's employment, not on whether the employer ... had authorized, expressly or impliedly, the commission of the tort ....").

152 DOBBS, supra note $10, \S 334$, at 907.

16 Id.

17 See infra Part II.C (discussing the difference in treatment of sexual and non-sexual intentional tort claims). 
will often rule out vicarious liability as a matter of law, taking the issue away from the jury. ${ }^{18}$ For the most part, U.S. legal scholars have not paid much attention to this disparity. ${ }^{19}$ Commentators have built their arguments around negligence cases, constructing their theories on the prototype of the employee who negligently drives the company vehicle. When we shift the frame to institutional liability for sexual abuse, however, we can see vicarious liability in a very different light.

This Article provides an explanation and a critique of the tort doctrine of vicarious liability as it plays out in sexual abuse and exploitation cases in the United States. Despite growing awareness of sexual abuse as a systemic injury and extensive media coverage of countless sex scandals, not that much has changed in the world of tort law, at least with respect to vicarious liability. ${ }^{20}$ Many courts continue to treat sexual abuse cases as exceptional, echoing the sentiments of oldfashioned (pre-1970s) criminal laws that once approached rape and sexual assault as qualitatively different from other forms of violence and erected special legal barriers to prosecution..$^{21}$ This Article refers to that phenomenon as "sexual exceptionalism." Seemingly untouched by developments in civil rights law that created new legal claims for sexual harassment and de-privatized sexual injuries, the vocabulary used in tort cases still often speaks of "lust" and "sexual desire" as forces entirely

18 E.g., Buck v. Blum, 130 S.W.3d 285, 287-88 (Tex. App. 2004).

19 Among U.S. scholars, only Alan Sykes engages in serious consideration of sexual abuse cases, devoting a section of his article to sexual harassment suits. Alan O. Sykes, The Boundaries of Vicarious Liability: An Economic Analysis of the Scope of Employment Rule and Related Legal Doctrines, 101 HARV. L. REv. 563, 603-08 (1988). Legal scholars in Canada, the United Kingdom, and Australia have written more extensively on sexual abuse and vicarious liability. See, e.g., Douglas Brodie, Enterprise Liability: Justifying Vicarious Liability, 27 OXFORD J. LEGAL STUD. 493, 495-96 (2007) (discussing equitable justifications for vicarious liability); Feldthusen, supra note 12, at 221-25 (discussing judicial decisions holding employers vicariously liable for sexual torts committed by their employees); Margaret Hall, After Waterhouse: Vicarious Liability and the Tort of Institutional Abuse, $22 \mathrm{~J}$. SOC. WELFARE \& FAM. L. 159, 161-65 (2000) (discussing a theory of institutional liability). See generally Peter Cane, Note, Vicarious Liability for Sexual Abuse, 116 L. Q. REv. 21 (2000) (discussing Canada's treatment of vicarious employer liability for the sexual abuse of children by employees).

20 There has been some evolution in the law governing "third-party" rape and sexual abuse cases when the claims are grounded in negligence. In such cases brought against landlords, businesses, schools, and other entities for failing to prevent sexual assaults, the key barrier to proving liability is establishing that the defendant owed a "duty" to protect the plaintiff against criminal assault. Ellen M. Bublick, Citizen No-Duty Rules: Rape Victims and Comparative Fault, 99 COLUM. L. REv. 1413, 1420-22 (1999); Martha Chamallas, Gaining Some Perspective in Tort Law: A New Take on Third-Party Criminal Attack Cases, 14 LEWIS \& CLARK L. REV. 1351, 1372-73 (2010); Sarah Swan, Triangulating Rape, 37 N.Y.U. REV. L. \& SOC. CHANGE 403, 443-44 (2013).

21 Chamallas, supra note 20, at 1374. 
removed from the public world of employment, despite the obvious effects of sexual abuse on victims in their capacity as consumers, patients, clients, and students in institutions that serve the public. ${ }^{22}$ In this respect, U.S. courts have not yet followed the lead of other common law countries, such as Canada and the United Kingdom, that have responded to the sexual abuse phenomenon by refashioning the doctrine of vicarious liability. ${ }^{23}$

Part II of this Article lays out the two prevailing tests that U.S. courts have used to determine whether an employee's act was committed "in the course and scope of employment": the restrictive "motive to serve" test and the more liberal approach focused on "enterprise risk" or "foreseeability." 24 Despite being the object of criticism for several decades, the restrictive "motive to serve" the employer's interest test is still applied by many U.S. courts with the predictable result that courts often have great difficulty finding that sexual abuse serves the employer's interests. ${ }^{25}$ However, even those courts that apply more liberal "enterprise risk" creation standards for vicarious liabilitycentered on foreseeability or predictability - do not consistently rule for sexual abuse plaintiffs, even when the risk of sexual abuse is common and predictable. ${ }^{26}$ Instead, the results of both tests are indeterminate, creating a considerable degree of confusion in the law.

To provide a contrast to the sexual abuse cases, Part II also examines cases of non-sexual violence committed by employees. ${ }^{27}$ Although results are far from uniform, courts in these cases seem more willing to impose vicarious liability. In canonical opinions, judicial luminaries such as Judge Learned Hand, ${ }^{28}$ Judge Friendly, ${ }^{29}$ Justice Traynor, ${ }^{30}$ and Judge Calabresi ${ }^{31}$ have seen fit to impose vicarious liability when

22 See, e.8., Lisa M. v. Henry Mayo Newhall Mem'l Hosp., 907 P.2d 358, 364 (Cal. 1995) ("'If ... the assault was not motivated or triggered off by anything in the employment activity but was the result of only propinquity and lust, there should be no liability." (emphasis added) (quoting Lyon v. Carey, 533 F.2d 649, 655 (D.C. Cir. 1976))).

23 See infra Part V.B (explaining the Canadian approach to vicarious liability).

24 See infra Parts II.A-B (discussing the "motive to serve" test and approaches based on "foreseeability" and "enterprise risk").

25 See infra Part II.A (discussing the inconsistent applications of the "motive to serve" test).

${ }^{26}$ See infra Part II.B (explaining the "enterprise risk" test and its failure to impose liability in several contexts where the conduct was foreseeable).

${ }_{27}$ See infra Part II.C (analyzing vicarious liability in the non-sexual intentional tort context).

28 Nelson v. American-West African Line, Inc., 86 F.2d 730, 731-32 (2d Cir. 1936).

29 Ira S. Bushey \& Sons, Inc. v. United States, 398 F.2d 167, 168, 171-73 (2d Cir. 1968).

30 Carr v. Wm. C. Crowell Co., 171 P.2d 5, 6, 8 (Cal. 1946).

31 Taber v. Maine, 67 F.3d 1029, 1031, 1037 (2d Cir. 1995). 
enraged and often drunken male employees engage in violent acts, but that stance has not carried over to the sexual abuse context.

Part III of this Article looks to the academic torts literature for an explanation of the principal rationales underlying the vicarious liability of employers. ${ }^{32}$ Whether focused on the goal of compensation, deterrence, or fairness, the scholarship offers a strong endorsement of the doctrine, supporting the courts' routine imposition of vicarious liability in cases of employee negligence. Beyond noting that vicarious liability provides a secure avenue of compensation for injured employees and a means for spreading the cost of injuries, scholars have articulated powerful economic arguments for imposing vicarious liability based on its capacity to provide employers with incentives to make the workplace safer. ${ }^{33}$ Both the major "law and economics" articles, as well as articles centered on fairness and justice, adopt the key concept of "enterprise causation," which asks whether the employment relation increased the probability that the offending employee would commit the tort, regardless of the employee's motivation. ${ }^{34}$ Part III concludes that the "motive to serve" test finds little support in the academic literature, which instead tends to map quite closely onto the more liberal tests for vicarious liability centered on risk creation and foreseeability. ${ }^{35}$

Part IV of the Article looks beyond legal doctrine and the mainstream academic torts literature to understand why U.S. courts have not routinely extended vicarious liability to cases of sexual misconduct. ${ }^{36}$ Drawing upon feminist theoretical accounts of rape and sexual harassment, this Part locates the roots of sexual exceptionalism in a traditional ideology that assimilates sexual abuse to consensual sexual conduct and often indiscriminately exempts even harmful sexual behavior from legal penalties. ${ }^{37}$ Focusing on feminist resistance to sexual exceptionalism in debates over rape and sexual harassment law, Part IV catalogues legal reform efforts that succeeded in introducing the victim's perspective into the law and simultaneously turning the law's attention away from the motives of the perpetrator and toward an emphasis on

32 See infra Part III (discussing three underlying rationales for vicarious liability: compensation, deterrence, and fairness).

33 See infra text accompanying notes 121-23 (explaining the law and economics theory of efficiency and how vicarious liability incentivizes employers to minimize employees' tortious conduct).

34 See infra text accompanying notes 118-19 (describing the theory of enterprise causation).

35 Infra note 158 and accompanying text.

36 See infra Part IV (examining feminist theory, cognitive psychology, and scholarship on institutional culture).

37 See infra Part IV.A (discussing sexual exceptionalism within the realm of feminist theory). 
the relative power and social position of the actors. ${ }^{38}$ In highlighting the importance of job-created power as a cause of sexual harassment, the feminist literature forged a connection between sexual misconduct and employment and laid the groundwork for holding employers responsible for sexual injury. ${ }^{39}$ These insights, however, did not carry over into tort law, which remained fixed on the sexual desire of the offending employee as a reason to exempt employers from liability.

Beyond the power dynamics and structural features of the workplace that facilitate sexual abuse, Part IV looks to cognitive psychology to explain the resiliency of the sex exception to vicarious liability. 40 This Part explores two common cognitive biases - the fundamental attribution error and the bias toward monocausality - that work in tandem to reinforce the tendency to fix attention on the (purported) sexual motivation of the individual offender to the exclusion of the other possible causes of sexual abuse, most prominently the situational features of the particular workplace. ${ }^{41}$

Part IV concludes with a discussion of interdisciplinary scholarship that analyzes "abusive institutional cultures" and makes the case for reconceptualizing the way we think about vicarious liability. ${ }^{42}$ Stressing the importance of framing the narratives we construct of sexual abuse in institutional settings, this genre of critical theory unpacks and criticizes the stock image of the offender as an "outsider" who infiltrates an otherwise healthy enterprise or organization. ${ }^{43}$ This framing of the problem misses the ways that certain institutional cultures facilitate and even create abusive behaviors, particularly in situations in which there is a norm of cultural deference that encourages vulnerable groups, such as children, to defer to authority figures. Part IV discusses the implications of re-conceptualizing our view of the institution as a "crucible" for certain types of abuse and developing a new view of institutional

\footnotetext{
38 See infra text accompanying notes 166-67, 172-77 (describing feminist reform efforts involving rape laws).

39 See infra text accompanying notes 195-98 (analyzing the concept of job-created power and its influence on courts).

40 See infra Part IV.B (utilizing cognitive psychology to explain why courts often fail to impose vicarious liability for sexual misconduct).

41 See infra text accompanying notes 206-07, 212-14 (discussing the fundamental attribution error and bias toward monocausality and how they may affect decision-making in sexual misconduct cases).

42 See infra Part IV.C (highlighting aspects of institutional cultures which facilitate sexual misconduct and arguing that the phrase "institutional liability" better reflects employer liability in such instances).

43 See infra text accompanying notes 221-25 (arguing that framing the offending employee as an "outsider" is a distorted portrayal of the institution and obscures the reality that institutional cultures may produce abusive behaviors in otherwise normal employees).
} 
liability that better captures the causal role of employers in sexual misconduct cases. ${ }^{44}$

Part V of the Article turns back to legal doctrine and discusses models for legal reform, including my own proposed rule for vicarious liability in sexual abuse cases. ${ }^{45}$ It explores two innovative doctrinal developments - one in the United States and the other in Canada - that emerged in the late 1990s, examining the U.S. Supreme Court's approach to employer liability in Title VII sexual harassment cases and the multifactor approach adopted by the Supreme Court of Canada in a tort case involving the sexual abuse of children in residential care. ${ }^{46}$ These precedents establish workable models for redirecting tort doctrine toward an "enterprise risk" approach based on the particular features of sexual abuse cases. They each highlight the importance of opportunity, power, intimacy, and vulnerability in assessing the employer's causal role in producing and facilitating sexual abuse in the employment context. ${ }^{47}$ Part $\mathrm{V}$ concludes with a defense of a rule-based proposal to reform U.S. tort law that would impose vicarious liability in sexual abuse cases whenever "an employer materially increases the risk of tortious action either by conferring power or authority on its employees over vulnerable persons or by regularly placing its employees in situations of intimate or personal contact with clients, customers, or other potential victims." 48

\section{PREVAILING TeStS FOR VICARIOUS LIABILITY}

\section{A. The "Motive to Serve" Test}

Although there are several variations on a theme, states generally employ one of two tests to determine "course and scope" of employment. The more restrictive test-the "motive to serve" or "purpose" test-comes from the Restatement of Agency (Second) and requires that the employee's action be "actuated, at least in part, by a

44 See infra text accompanying notes 228-29 (explaining the crucible theory of vicarious liability).

45 See infra Part V (analyzing the U.S. standard for vicarious liability in Title VII sexual harassment cases, the Canadian approach to vicarious liability in tort cases, and proposing a tort rule for U.S. courts).

46 See infra Parts V.A-B (describing the Title VII standard for vicarious liability, including an affirmative defense, and discussing the multi-factor approach to vicarious liability adopted by Canadian courts).

47 See infra text accompanying notes 294-308 (discussing important factors to consider in determining whether to impose vicarious liability for sexual abuse in the employment context).

$48 \quad$ See infra Part V.C (proposing a new standard of vicarious liability for sexual abuse cases). 
purpose to serve the master." 49 As one can well imagine, it is difficult to characterize a sexual abuser's action as furthering the employer's mission and even more difficult to prove that the offender had the employer's interests in mind when he committed the abuse. Starting in the 1960s, however, many courts abandoned the "motive to serve" test and adopted more liberal tests for vicarious liability that center on the risks created by the enterprise. ${ }^{50}$ These courts ask, for example, whether the employee's act was "engendered by" the employment, 51 was "foreseeable" 52 in the sense that it was a predictable risk, ${ }^{53}$ was an "outgrowth" of the employment, ${ }^{54}$ or whether it was "not so unusual or startling." 55

At first blush, these more liberal tests would seem more conducive to imposing vicarious liability in the sexual abuse context, particularly given that sexual abuse cases are so common. However, the choice of standard does not always determine the outcome. First, an occasional court will stretch the "motive to serve" test to find vicarious liability. These liberal "motive to serve" decisions emphasize that vicarious liability may be imposed in cases of mixed motives when a "motive to serve" the employer is only one of multiple motives behind an employee's action.56 Thus, in 2001, the District of Columbia Court of

49 RestatemENT (SECOND) OF AGENCY $\$ 228(1)$ (c) (1958). Section 228 of the Restatement of Agency (Second) provides in full:

Conduct of a servant is within the scope of employment if, but only if:

(a) it is of the kind he is employed to perform; (b) it occurs substantially within the authorized time and space limits; (c) it is actuated, at least in part, by a purpose to serve the master, and (d) if force is intentionally used by the servant against another, the use of force is not unexpectable by the master.

Id. $\$ 228(1)$.

50 E.g., Fearing v. Bucher, 977 P.2d 1163, 1168 (Or. 1999).

51 Lisa M. v. Henry Mayo Newhall Mem'1 Hosp., 907 P.2d 358, 363 (Cal. 1995) (quoting Carr v. Wm. C. Crowell Co., 171 P.2d 5, 8 (Cal. 1946)).

$52 \quad$ Fahrendorff $e x$ rel. Fahrendorff v. N. Homes, Inc., 597 N.W.2d 905, 911 (Minn. 1999) (citing Marston v. Minneapolis Clinic of Psychiatry \& Neurology, Ltd., 329 N.W.2d 306, 311 (Minn. 1982)).

53 See Lisa M., 907 P.2d at 364 ("The employment must be such as predictably to create the risk employees will commit intentional torts of the type for which liability is sought.").

54 Id. at 363 (quoting Carr, 171 P.2d at 8); John R. v. Oakland Unified Sch. Dist., 769 P.2d 948, 964 (Cal. 1989) (Kaufman, J., concurring and dissenting) (internal quotation marks omitted) (citing Martinez v. Hagopian, 227 Cal. Rptr. 763, 767 (Cal. Ct. App. 1986)).

55 Mary M. v. City of Los Angeles, 814 P.2d 1341, 1344 (Cal. 1991) (quoting Perez v. Van Groningen \& Sons, Inc., 719 P.2d 676, 678 (Cal. 1986)); Rodgers v. Kemper Constr. Co., 124 Cal. Rptr. 143, 149 (Cal. Ct. App. 1975).

56 See, e.g., Fearing v. Bucher, 977 P.2d 1163, 1164-65, 1167 (Or. 1999) (imposing vicarious liability on an archdiocese for a priest's sexual abuse of a minor where the relationship began as part of ordinary priestly duties); Lourim v. Swensen, 977 P.2d 1157, 1158, 1160-61 
Appeals ruled that vicarious liability could be imposed in a case where a security guard at Safeway Stores molested a twelve-year-old girl accused of shoplifting some candy. ${ }^{57}$ The guard fondled her breasts, touched her genital area, and popped her bra strap, ${ }^{58}$ in what could only have been a very humiliating experience for a young girl. The court reasoned that, because a physical search of a suspected shoplifter was designed in part to uncover stolen goods, it passed the "motive to serve" test. ${ }^{59}$

Far more frequently, however, application of the "motive to serve" test results in no vicarious liability. ${ }^{60}$ Thus, in a 2004 Texas case, the court ruled that there was no vicarious liability as a matter of law when a neurologist assaulted his patient during the course of an examination. ${ }^{61}$ To examine the strength of his patient's hand, the doctor asked the patient to put her hands behind her back and squeeze an object. ${ }^{62}$ First, the doctor placed a metal weight into plaintiff's hands. Then, however, he placed plaintiff's hand on his penis. ${ }^{63}$ The court exonerated the employer, ruling that the doctor was acting for his own prurient interest and that the neurological exam was a "pretense" for his own personal gratification. ${ }^{64}$

The comparison of the two cases illustrates how malleable the "motive to serve" test can be: the Texas court, like the D.C. court, could easily have ruled that because the plaintiff was assaulted in the course of a neurological examination, the employer's, as well as the employee's, interests were also being served. It is difficult to understand why a search for stolen goods is so different from an examination to detect disease, given that in the first instance the employer is in the business of selling goods, while in the second instance the employer is in the business of treating disease.

(Or. 1999) (imposing liability on Boys Scouts of America for sexual abuse by a volunteer troop leader where the troop leader's motives were mixed).

57 Brown v. Argenbright Sec., Inc., 782 A.2d 752, 755, 757 (D.C. App. 2001).

58 Id. at $755-56$.

$59 \quad$ Id. at 758.

60 See, e.g., Bernie v. Catholic Diocese of Sioux Falls, 821 N.W.2d 232, 235-36, 239-40 (S.D. 2012) (finding no vicarious liability for sexual abuse committed by monks and nuns in an elementary boarding school on a Sioux Reservation); Birkner v. Salt Lake Cnty., 771 P.2d 1053, 1055, 1058 (Utah 1989) (finding no vicarious liability for sexual misconduct of a social worker who abused a patient during therapy sessions).

61 Buck v. Blum, 130 S.W.3d 285, 290 (Tex. App. 2004).

62 Id. at 287-88.

$63 \quad$ Id. at 288.

64 Id. at 290; see Doe v. Fulton-DeKalb Hosp. Auth., 628 F.3d 1325, 1327, 1334-35 (11th Cir. 2010) (finding no vicarious liability for sexual harassment of patients by a substance abuse counselor who "pursue[d] his own sexual agenda" and acted for purely personal reasons). 


\section{B. Foreseeability and "Enterprise Risk" Tests}

There is a similar unpredictability attending application of the more liberal "enterprise risk" standards. True to expectation, some courts have applied the more liberal standards in a manner that authorizes imposition of vicarious liability in sexual tort cases. The Oregon Supreme Court, for example, ruled that an archdiocese could be held liable for the sexual abuse of a minor by his parish priest, reasoning that a jury could find the priest's pastoral duties were a "necessary precursor to the sexual abuse," a "direct outgrowth" of the priest's employment, and "engendered" by the employment.65 Similarly, using the foreseeability test, the Minnesota Supreme Court ruled that a group home may be held liable for sexual abuse committed by a counselor, describing such abuse as a "well known hazard" in such a setting. ${ }^{66}$

More surprising, however, is the number of courts that have applied the more liberal "enterprise risk" standard yet nonetheless refused to impose vicarious liability in the sexual abuse context. One of the most controversial cases comes from the California Supreme Court. In 1995, a divided court declared there could be no vicarious liability in a case where a medical technician molested a nineteen-year-old pregnant woman who went to the hospital for an ultrasound. ${ }^{67}$ The technician asked the plaintiff if she wanted to know her baby's sex.68 He first rubbed the wand around and then inside her vagina, even though the ultrasound did not require a transvaginal procedure. ${ }^{69}$ Then, he told her he needed to use his fingers and excite her to get a good picture of the baby. ${ }^{70}$ Plaintiff thought the conduct was a regular part of the procedure until her obstetrician later told her that the technician's conduct was improper. ${ }^{71}$ Although intimate contact with patients was an inherent part of this job, the court did not regard the abuse as "engendered" by the employment, repeating an oft-cited passage to the effect that there could be no vicarious liability "[i]f ... the assault was not motivated or

65 Fearing v. Bucher, 977 P.2d 1163, 1165, 1168 (Or. 1999).

66 Fahrendorff ex rel. Fahrendorff v. N. Homes, Inc., 597 N.W. 2d 905, 912-13 (Minn. 1999); see Doe v. Samaritan Counseling Ctr., 791 P.2d 344, 348 (Alaska 1990) (imposing vicarious liability because sexual abuse was "reasonably incidental" to the therapist's legitimate counseling activities).

67 Lisa M. v. Henry Mayo Newhall Mem'l Hosp., 907 P.2d 358, 359, 367 (Cal. 1995).

68 Id. at 360 .

69 Id.

$70 \quad$ Id.

71 Id. 
triggered off by anything in the employment activity but was [a] result of only propinquity and lust."72

It is not just that the court was reluctant to impose vicarious liability in the medical context. Another prominent California Supreme Court case also refused to impose vicarious liability when a teacher molested a ninth grade boy in the teacher's apartment. ${ }^{73}$ The boy had come to the teacher's apartment in connection with an officially-sanctioned extracurricular program where he was to receive academic credit for helping the teacher grade papers. ${ }^{74}$ Following a common script of child predators, the teacher tried to convince the boy that engaging in sex acts with him would be "a constructive part of their relationship," then said he would fail the boy if he did not comply, and finally threatened to retaliate against him if he revealed what took place. ${ }^{75}$ In the end, the court found that "the connection between the authority conferred on teachers ... and the abuse of that authority to indulge in personal, sexual misconduct [was] simply too attenuated" to allow for the imposition of vicarious liability. ${ }^{76}$ The dissent accused the majority of having its "head[] in the sand" and refusing to accept the hard truth that sexual assaults in the home, workplace, and schools are not uncommon occurrences. ${ }^{77}$

Despite its embrace of the liberal test for the imposition of vicarious liability, in recent years the California Supreme Court has only seen fit to allow the imposition of vicarious liability in a sexual abuse case involving a police officer who raped a motorist he stopped for erratic driving. ${ }^{78}$ The court's narrow holding in Mary M. v. City of Los Angeles cited the "unique position of trust" that police officers hold in our society and stressed that when the officer encountered the plaintiff he was equipped with visible symbols of power, including a distinctively marked car, a uniform, badge, and gun. ${ }^{79}$ Tellingly, a lower California court refused to extend even this slim pocket of vicarious liability in a similar case involving a private security guard who raped a motorist he stopped for drunk driving, even though that guard was also wearing a uniform, drove a marked vehicle with a spotlight, and carried a gun and

72 Id. at 364 (quoting Lyon v. Carey, 533 F.2d 649, 655 (D.C. Cir. 1976)) (internal quotation marks omitted).

73 John R. v. Oakland Unified Sch. Dist., 769 P.2d 948, 949 (Cal. 1989).

74 Id.

$75 \quad I d$

$76 \quad$ Id. at $956-57$.

77 Id. at 965 (Kaufman, J., concurring and dissenting).

78 Mary M. v. City of Los Angeles, 814 P.2d 1341, 1342 (Cal. 1991). For a similar holding, see Applewhite v. City of Baton Rouge, 380 So. 2d 119, 121 (La. Ct. App. 1979).

$79 \quad 814$ P.2d at 1342. 
handcuffs. ${ }^{80}$ The lower court apparently got the message that in the decade since the high court had imposed liability in Mary M., it had come to embrace a restrictive approach to vicarious liability in the sexual tort context, ${ }^{81}$ a move that had the effect of limiting Mary $M$. to its facts.

\section{Non-Sexual Intentional Misconduct}

Aside from being indeterminate and generally under-protective of victims, the two traditional tests for determining course and scope of employment have also embraced a double standard, reflecting a kind of sexual exceptionalism that treats sex abuse cases differently from other intentional tort cases.82 Some courts have not been shy about expressing their "sex is different" approach, flatly stating that "sexual misconduct falls outside the course and scope of employment." 83 For these courts, the possibility that the employee was motivated by sexual desire, gratification, or lust marks it as qualitatively different from other tort cases, even other intentional tort cases. ${ }^{84}$ Most courts, however, are less explicit about carving out a sex exception but simply find it easier to impose vicarious liability in cases involving non-sexual violence and misconduct, especially when drunken male employees behave badly.

Thus, one of the iconic vicarious liability opinions authored by Judge Friendly in 1968, Ira S. Bushey $\mathcal{E}$ Sons, Inc. v. United States, involved a drunken seaman who returned late at night from shore leave "in the condition for which seamen are famed." 85 In this inebriated state, the seaman turned three large wheels on the drydock wall, some twenty times, opened the valves, and flooded the ship and drydock. ${ }^{86}$ For Judge

80 Maria D. v. Westec Residential Sec., Inc., 102 Cal. Rptr. 2d 326, 327, 340 (Cal. Ct. App. 2000).

81 The California Supreme Court began to shift in a conservative direction following a 1986 election that ousted Chief Justice Rose Bird and two other liberal members from the court. Philip Hager, Now in Minority on State Court: Broussard: Liberal Justice Maintains Steady Course, L.A. TimEs (Aug. 8, 1988), http://articles.latimes.com/1988-08-08/news/mn169_1_state-supreme-court.

82 See supra text accompanying note 21 (discussing judicial treatment of sexual abuse cases as exceptional).

83 Cockrell v. Pearl River Valley Water Supply Dist., 865 So. 2d 357, 362 (Miss. 2004); see Doe v. Fulton-Dekalb Hosp. Auth., 628 F.3d 1325, 1333 (11th Cir. 2010) (explaining that sexual misconduct torts "'being purely personal in nature, are unrelated to the employee's duties and, therefore, are outside the scope of employment because they are not in furtherance of the master's business'" (quoting Alpharetta First United Methodist Church v. Stewart, 472 S.E.2d 532, 536 (Ga. Ct. App. 1996))); Gibson v. Brewer, 952 S.W.2d 239, 246 (Mo. 1997) ("Intentional sexual misconduct ... [is] not within the scope of employment....").

$84 \quad$ Supra note 83.

$85 \quad 398$ F. 2d 167, 168 (2d Cir. 1968).

86 Id. 
Friendly, the seaman's conduct was not so unforeseeable that it was unfair to charge the defendant with responsibility, even though before the incident the seaman had an unblemished record.87 Friendly stressed that the foreseeability required to hold an employer vicariously liable was "quite a different thing from the foreseeably unreasonable risk of harm that spells negligence." 88 To impose vicarious liability, Friendly ruled that the court need only regard the risk as "characteristic of [the] activities" of the enterprise. ${ }^{89}$ In Judge Friendly's view, seamen often get drunk and get into trouble, ergo the employer should not be surprised when incidents like that in Bushey happen.90

Twenty-six years later, another famous judge, Judge Guido Calabresi, endorsed Judge Friendly's liberal approach to vicarious liability in a case involving a tort committed by yet another off-duty drunken sailor who first became intoxicated at a party on the base and then later in the evening crashed his vehicle into the plaintiff's car while driving back to the base. ${ }^{91}$ Calabresi emphasized that all that happened was to be expected, citing Friendly's words that "[t]he proclivity of seamen to find solicitude by copious resort to the bottle... has been noted in opinions too numerous to warrant citation."92 For Calabresi, this conventional wisdom made the sailor's actions "a completely foreseeable event, in the sense that it is a reasonably obvious risk of the general enterprise." 93

The willingness to extend vicarious liability to cover non-sexual violence can also be seen in opinions from the California Supreme Court, ${ }^{94}$ the same court that refused to impose vicarious liability in the ultrasound case and in the student extracurricular activity/molestation case. In one case, for example, the court allowed vicarious liability to be imposed when off-duty construction workers got drunk but remained on

\footnotetext{
87 Id. at $169,171$.

88 Id. at 171 (quoting 2 HARPER \& JAMES, THE LAW OF TORTS 1377-78 (1956)).

89 Id.

90 Id. at 172; see Nelson v. American-West African Line, Inc., 86 F.2d 730, 732 (2d Cir. 1936) (permitting a jury to impose vicarious liability for violent acts of a drunken boatswain) (opinion by Judge Learned Hand).

91 Taber v. Maine, 67 F.3d 1029, 1031-32 (2d Cir. 1995).

92 Id. at 1037 (quoting Ira S. Bushey \& Sons, Inc. v. United States, 398 F.2d 167, 172 (2d Cir. 1968)) (internal quotation marks omitted).

93 Id.

94 See, e.g., Carr v. Wm. C. Crowell Co., 171 P.2d 5, 6-7 (Cal. 1946) (holding an employer vicariously liable when an employee threw his carpenter's hammer at another employee causing serious head injury) (opinion by Justice Traynor). Other California courts have ruled similarly. See, e.g., Rodgers v. Kemper Constr. Co., 124 Cal. Rptr. 143, 146, 152 (Cal. Ct. App. 1975) (holding a subcontractor vicariously liable when two employees assaulted the plaintiff at a construction job site).
} 
the job site and then brutally attacked two other workers, kicking and beating them with their fists, rocks, and a hardhat, ultimately rendering one unconscious and permanently injuring the eye of the other. ${ }^{95}$ Significantly, the employees' rage did not lead the court to regard the action as personal. Instead, quoting an earlier decision by Justice Traynor, the court viewed the display of emotion at the workplace as "expressions of human nature ... inseparable from working together" and remarked that "[m]en do not discard their personal quali[t]ies when they go to work." 96 The court justified its conclusion that the violence was committed in the scope of employment by noting that the victim and assailant did not know each other personally aside from work and that their dispute arose on the work site. ${ }^{97}$ Of course, however, the same could be said about the technician who molested the patient during the ultrasound procedure. .8

Beyond the acts of drunken men, courts are often able to see a connection between employment and violent acts by employees-even rare criminal acts-provided that they are not sexual in nature. In a dramatic ruling, the Supreme Court of Oklahoma allowed a jury to determine whether a daycare facility should be held vicariously liable for the acts of a caregiver who fractured a baby's skull. ${ }^{99}$ Frustrated when she could not stop the baby from crying, the caregiver struck the baby's head against a shelf two times. 100 The employee subsequently pled guilty to criminal battery and received a ten-year criminal sentence. ${ }^{101}$ Despite her shocking behavior, the court viewed the employee's acts as "incident to some service being performed for the employer" and as "aris[ing] out of an emotional response to actions being taken for the employer." 102 Generously characterizing the violence as an "attempt to quiet the crying infant," the court regarded the employee's acts as jobrelated, despite the employee's personal emotional reaction. ${ }^{103}$ The emotions of anger and frustration were thus treated differently from sexual desire or sexual gratification, despite the personal nature of both kinds of emotions.

\footnotetext{
95 Rodgers, 124 Cal. Rptr. at 146-47, 152.

\% Id. at 151 (quoting Carr, 171 P.2d at 7) (internal quotation marks omitted).

97 Id. at 150-51.

98 See Lisa M. v. Henry Mayo Newhall Mem'l Hosp., 907 P.2d 358, 359 (Cal. 1995) (holding that a hospital was not vicariously liable when a technician molested a patient during an ultrasound procedure).

99 Baker v. Saint Francis Hosp., 126 P.3d 602, 603, 608 (Okla. 2005).

100 Id. at 604

101 Id.

102 Id. at 605 (quoting Rodebush v. Okla. Nursing Homes, Ltd., 867 P.2d 1241, 1245 (Okla. 1993)).

103 Id.
} 
Although there will always be distinguishing factors that advocates can argue to place a case on one side of the line rather than another, ${ }^{104}$ there does seem to be a special reluctance on the part of many courts to hold employers vicariously liable for sexual misconduct, even as compared to other intentional torts that do not advance the employer's interests. In particular, anger and violence of men ("boys being boys") somehow strikes courts as characteristic of employment in maledominated workplaces. But even violent acts of women are sometimes viewed as characteristic of a particular employment and within the course and scope of employment. It is not the gender of the actors that triggers the exceptional treatment but the perceived sexual nature of the act. In vicarious liability cases, it is sexual misconduct that is singled out as exceptional and treated as personal, private, and unconnected to employment.

In a prominent Title VII sexual harassment case, Justice Souter remarked on this confusing body of tort cases, noting that "their disparate results do not necessarily reflect widely varying terms of the particular employment contracts involved, but represent differing judgments about the desirability of holding an employer liable for his subordinates' wayward behavior." 105 Justice Souter argued that the law should keep up with the times, offering the example that older cases treated an employee's smoking during work hours as outside the scope of employment, while more recently courts have held smoking on the job falls within the scope of employment. ${ }^{106}$ Stressing the normative judgment that often underlies a determination of vicarious liability, Justice Souter stated:

It is not that employers formerly did not authorize smoking but have now begun to do so, or that employees previously smoked for their own purposes but now do so to serve the employer. We simply understand smoking differently now and have revised the old judgments about what ought to be done about it. 107

While the pendulum may have swung yet again on the issue of smoking, Justice Souter's point about tailoring vicarious liability to new understandings of social behavior is well taken.

104 See, e.g., Ferris v. S.L. Capital Corp., 734 N.Y.S.2d 36, 36 (N.Y. App. Div. 2001) (raising a jury question about whether to hold an employer vicariously liable in a "road rage" case).

105 Faragher v. City of Boca Raton, 524 U.S. 775, 796 (1998).

$106 \quad$ Id. at 797.

107 Id. 


\section{FIRST PRINCIPLES: THE ACADEMIC TORTS LITERATURE}

To decide how cases of sexual misconduct should be handled, it is necessary to go back to first principles and examine the rationales for imposing vicarious liability more generally. Like so many other doctrines in tort law, three fundamental reasons are frequently cited by scholars in defense of vicarious liability: compensation, deterrence, and fairness. ${ }^{108}$ Because the three rationales converge to support imposition of strict liability in the employment context, contemporary scholars have tended to endorse vicarious liability, at least in cases of employee negligence.

Even critics of vicarious liability acknowledge that the doctrine accomplishes the goal of victim compensation. ${ }^{109}$ As a form of strict liability, vicarious liability insures access to the "deep pocket" of enterprises and means that victims do not have to rest on the hope that their abusers are personally wealthy. ${ }^{110}$ This is no small virtue and goes a long way toward explaining the resilience of vicarious liability despite the gravitational pull of the negligence principle in tort law. It is certainly true that, if employers were not wealthier as a class than their employees, we would have no need for vicarious liability. ${ }^{111}$ Moreover, at least since the 1960s, commentators have pointed out that as a form of strict liability imposed on enterprises, vicarious liability also accomplishes the objective of loss spreading or loss distribution, by which the cost of the injury "is distributed over a large section of the community, and spread over some period of time."112 Rather than saddle a victim with a huge uncompensated loss, the loss can be insured against ${ }^{113}$ and passed off or distributed to large numbers of consumers or

108 Christopher J. Robinette, Torts Rationales, Pluralism, and Isaiah Berlin, 14 GEO. MASON L. REV. 329, 329 (2007).

109 T. BATY, VICARIOUS LIABILITY: A SHORT HISTORY OF THE LIABILITY OF EMPLOYERS, PRINCIPALS, PARTNERS, ASSOCIATIONS AND TRADE-UNION MEMBERS WITH A CHAPTER ON THE LAWS OF SCOILAND AND FOREIGN STATES 154 (1916). The author famously concluded that the only persuasive justification for vicarious liability was that servants were an "impecunious race," and that the doctrine allowed damages to be taken from a deep pocket. Id. at $147,154$.

110 Of course, some abusers will have sufficient assets to satisfy a judgment. See Schwartz, supra note 9, at 1757 (explaining that many "middle managers have ample wealth that would make the threat of liability very real to them").

111 ATIYAH, supra note 8, at 22 ("[T]he doctrine of vicarious liability would never have got going at all if ... employers were not generally wealthier than their servants ....").

112 Id. at 23.

113 Notably, the "intentional injury" exclusion that often bars insurance coverage for intentional torts committed by an insured does not apply when the insured is vicariously liable rather than personally at fault. See NEGLiGENCE IN EMPLOYMENT LAW 206 (Alfred G. Feliu \& Weyman T. Johnson eds., 2002) (stating that the "intentional injury" exclusion often 
shareholders who are not likely to feel the pinch of the incremental loss nearly as sharply. The great value of such loss spreading-particularly in a nation such as the United States, with its skimpy social welfare system - is that it serves to prevent some unfortunate victims from descending into poverty and becoming dependent on government welfare programs, a public concern that sparked the workers' compensation movement for industrial accidents in the late nineteenth century. ${ }^{114}$

The desire for compensation and loss spreading alone, however, cannot serve as a complete justification for vicarious liability. Otherwise, the United States would have adopted a more comprehensive no-fault system for accidents and harms, rather than relying on our system of tort law, which operates to select out only a small percentage of those suffering injuries to receive compensation. ${ }^{115}$ Instead, tort doctrines are generally also justified either on the basis that they prevent or deter accidents or that they allocate burdens in a fair and equitable fashion-two reasons that map respectively onto the "law and economics" and "corrective justice" schools of tort theory that enjoy the most currency among U.S. tort scholars. 116

\section{A. The Economic Case for Vicarious Liability}

Many scholars - particularly those employing a law and economics approach - have analyzed vicarious liability based on its capacity to deter, considering whether vicarious liability is an economically efficient

bars insurance coverage for intentional torts committed by an insured but does not apply when the insured is vicariously liable rather than personally at fault); see also ROBERT E. KEETON \& ALAN I. WIDISS, INSURANCE LAW: A GUIDE TO FUNDAMENTAL PRINCIPLES, LEGAL DOCTRINES, AND COMMERCIAL PRACTICES 528 (1988) ("In most circumstances, courts hold both (1) that the express provisions commonly used in liability insurance policies do not preclude coverage for damages awarded for an intentional tort when the insured is held to be responsible on a theory of vicarious liability, and (2) that it would not be appropriate to imply a limitation that would restrict the coverage."); Christopher C. French, Debunking the Myth that Insurance Coverage Is Not Available or Allowed for Intentional Torts or Damages, 8 HASTINGS BUS. L.J. 65, 89-90 (2012) (stating that courts have allowed coverage when vicarious liability is imposed in situations where an employee intentionally injures another).

114 ATTYAH, supra note 8, at 23-24; see JOHN FABIAN WITT, THE ACCIDENTAL REPUBLIC: CRIPPLED WORKINGMEN, DESTTTUTE WIDOWS, AND THE REMAKING OF AMERICAN LAW 12829 (2004) (discussing historical accounts of workmen's compensation).

115 See DEBORAH R. HENSLER ET AL., COMPENSATION FOR ACCIDENTAL INJURIES IN THE UNITED STATES 107-08 (1991) (stating that tort liability payments comprise only twenty-two percent of the total compensation for economic and intangible losses in nonfatal accidents in the United States).

116 See Martha Chamallas \& JenNifer B. Wriggins, The Measure of InJury: Race, GENDER, AND TORT LAW 13-17 (2010) (discussing dominant tort theories). 
way to reduce accidents. ${ }^{117}$ One important contribution made by these economic scholars is the notion of "enterprise causation" - the idea that to determine whether an activity ought to be regarded as a cost of doing business, "[t]he crucial variable... is the extent to which the employment relation increases the probability of each wrong." 118 In his leading article, Alan Sykes formulates the test this way: "[a]n enterprise 'fully causes' the wrong of an employee if the dissolution of the enterprise and subsequent unemployment of the employee would reduce the probability of the wrong to zero."119 This test forces one to ask, for example, whether the offending employee was materially aided in his wrongdoing by having the job or position he occupied. Sykes concludes that even if an employee's tort is personally motivated, it is efficient to impose vicarious liability on the employer if the tort was caused at least in part by the employment relationship. ${ }^{120}$ This shift in focus from motivation to causation is a particularly critical move when analyzing vicarious liability for intentional torts, which are frequently classified as personally motivated but nonetheless may be "caused" by the employment relationship under Sykes's probabilistic notion of causation.

In making the efficiency case for vicarious liability, scholars have argued that vicarious liability encourages employers to be creative in their search for ways to make the workplace safer. ${ }^{121}$ Under this view, vicarious liability functions to reinforce fault liability. ${ }^{122}$ The Canadian Supreme Court expressed this idea as follows:

Beyond the narrow band of employer conduct that attracts direct liability in negligence lies a vast area where imaginative and efficient administration and supervision can reduce the risk that the employer has introduced into the community. Holding the employer

\footnotetext{
117 Sykes, supra note 19 , at 569.

118 Id. at 571-72; see Marie T. Reilly, A Paradigm for Sexual Harassment: Toward the Optimal Level of Loss, 47 VAND. L. REV. 427, 456-57 (1994) (discussing Sykes's theory of "probabilistic causation" through various examples).

119 Sykes, supra note 19, at 572. Sykes also considered situations of multiple causes where "the dissolution of the enterprise and subsequent unemployment of the employee would reduce the probability of the wrong but not eliminate it." Id.

$120 \quad$ Id. at $572-73$.

121 Id. at 569-70.

122 Brodie, supra note 19, at 495; see William M. Landes \& Richard A. Posner, The Positive Economic Theory of Tort Law, 15 GA. L. REV. 851, 914-15 (1981) (providing examples of ways employers may attempt to reduce the risk of accidents committed by their employees).
} 
vicariously liable for the wrongs of its employee may encourage the employer to take such steps . ..."123

In arguing that strict liability is superior to negligence, Gary Schwartz points out that it is not enough to presume that a plaintiff has an adequate remedy by positing that the employee could simply identify an untaken precaution, prove the employer's negligence, and render the imposition of vicarious liability unnecessary. ${ }^{124}$ Instead, as a practical matter, specific evidence of negligence may be difficult for plaintiffs to produce because "the employer's failure to adopt a precaution might lurk in the background," making it hard for a plaintiff to discover and demonstrate the employer's failure to the satisfaction of a judge and jury. ${ }^{125}$ Vicarious liability under this account saves the cost of investigating the existence of the untaken precaution and then litigating the negligence issue. Schwartz concludes that " $t]$ he intriguing benefit of strict liability, therefore, is that it can do a better job than a negligence regime in achieving that regime's own goal of encouraging the employer's cost-justified risk-reducing measures."126 This argument explains why permitting direct negligence claims against employers for identified inadequacies in screening and monitoring potentially risky employees is regarded by many economic scholars as insufficient to deter tortious employee behavior.

Of course, economic-minded scholars also express concern that imposing liability on the employer might take the pressure off the offending employee and thereby reduce his incentive not to offend. ${ }^{127}$ At this point, it bears mentioning that under well-established law an employer who is held vicariously liable for an employee's tortious action has a common law right to seek indemnification from the offending employee for the full extent of the damages. ${ }^{128}$ Vicarious liability thus does not supplant the offending employee's liability but simply provides the victim another avenue of redress. If employers routinely exercised their indemnity rights, the vicarious liability scheme could surely be said

\footnotetext{
123 Bazley v. Curry, [1999] 2 S.C.R. 534, para. 33 (Can. B.C.).

124 Schwartz, supra note 9, at 1760.

125 Id.

126 Id.

127 See Sykes, supra note 19 , at 570.

128 RESTATEMENT (THIRD) OF TORTS: APPORTIONMENT OF LIABILITY $\S 22$, illus. 2 (2000). It is only in the special situation of public employees sued under federal or state tort claims acts that the law assigns the ultimate responsibility to the employer. Such acts provide that the public entity must defend the action taken against the employee and "pay any claim or judgment against the employee in favor of the third party plaintiff." E.g., Farmers Ins. Grp. v. Cnty. of Santa Clara, 906 P.2d 440, 446 (Cal. 1995).
} 
to deter offending employees, as well as employers, from engaging in acts that might lead to liability.

Quite rightly, however, scholars have questioned whether the indemnity right is of practical significance because it is so rarely used. ${ }^{129}$ Indeed, employers' failure to seek indemnification has been so consistent over time that there has even been speculation that such failure might render the waiver of indemnification rights an implied condition of the employment contract. ${ }^{130}$ Particularly, if the employee is insolvent and knows he will not be sued, economic-minded scholars will likely remain concerned that the employee might be "undeterred, or ... underdeterred." 131

The literature yields no definitive answers as to why employers do not exercise their indemnification rights. With negligence cases in mind, Schwartz speculates that employers may prefer to attempt to disprove the employee's negligence and, in an effort to secure the employee's cooperation, may decide to forego an indemnification action. ${ }^{332}$ Additionally, employers understand that in some cases of "absentminded[]" or uncertain negligence on the employee's part, the negligence may be difficult to prevent or the employee may have sincerely wished to promote an employer's interests. ${ }^{133}$ Finally, Schwartz explains that pursuing an indemnification action is "bound adversely to affect the relationship between employer and employee" and "negatively affect the employer's standing with its workforce as a whole." 134

It is telling that none of Schwartz's explanations have much force in cases of sexual abuse or exploitation, in which it would seem that employers would want to distance themselves from the offending employee as much as possible. In such cases, at least when the charges of abuse are substantiated, bringing an indemnification action is one possible way for the employer to attempt to place the blame on the employee and to demonstrate that the actions of the employee are antithetical to the goals of the organization. Thus, if vicarious liability were imposed routinely in sexual abuse cases, we might well witness more claims for indemnification.

Aside from the prospect that the offending employee will face an indemnity suit by the employer, Sykes meets the concern for deterrence

129 See, e.g., Schwartz, supra note 9, at 1753 ("[I]ndemnification claims by employers against negligent employees are exceedingly rare.").

130 Id. at 1753-54.

131 Id. at 1756.

132 Id. at $1764-65$.

133 Id. at $1765-66$.

$134 \quad$ Id. at 1765. 
by arguing that offending employees have sufficient incentives to avoid misconduct under a vicarious liability regime. ${ }^{135}$ Once exposed to liability, their employers will likely discipline the offending employees through firing, denial of promotions, and other actions. ${ }^{136}$ Particularly, for judgment-proof employees, the threat of termination or discipline may well be more potent than the threat of a lawsuit. Thus, a strong case can be made that the imposition of vicarious liability does not reduce the incentive for employees to refrain from offending in the first place and is not likely to backfire and promote misconduct rather than deter it.

Finally, some economic scholars also worry that the imposition of vicarious liability loses sight of the role that victims play in the creation of their own injuries. For example, in the employee negligence context, Sykes argues that when tort victims can take precautions to guard against being injured, a rule of strict liability with a contributory negligence defense is superior to a rule that takes no account of victim fault. ${ }^{137}$ Other law and economics scholars agree. ${ }^{138}$ However, it is unclear whether these scholars' support for a victim fault defense would carry over to the intentional torts context. Importantly, when it comes to victim responsibility for sexual abuse, the definition of victim "fault" is far more complex and contested, especially since the offending employee's liability is predicated on intent, not negligence. ${ }^{139}$ In sexual abuse cases, a strong argument can be made that it is unjust to make victims shoulder the burden of preventing their own rapes and assaults. As Ellen Bublick has forcefully argued, every citizen "should be entitled to shape her life around the assumption that others will not intentionally rape her." ${ }^{140}$ In any event, as will be discussed in more depth later, ${ }^{141}$ the

\footnotetext{
135 Sykes, supra note 19 , at 570.

136 Id.

$137 \quad$ Id. at 579.

138 See, e.g., Schwartz, supra note 9, at 1762. With the adoption of comparative negligence, many states have allowed even strictly liable defendants to assert a defense of comparative negligence to limit the defendant's liability. See, e.g., Wagner v. Grinnell Hous. Dev. Fund Corp., 746 N.Y.S.2d 156, 157 (N.Y. App. Div. 2002) (assigning share to a negligent plaintiff fifteen percent at fault when the defendant was vicariously liable), affd, 785 N.E.2d 729 (N.Y. 2003); see also RESTATEMENT (THIRD) OF TORTS: APPORTIONMENT OF LIABILITY § 1 (2000) (applying comparative principles to tort claims, regardless of the basis of liability).

139 See Chamallas, supra note 20, at 1380-86 (discussing the victim fault defense in sexual abuse cases); see also Bublick, supra note 20, at 1441-42 (questioning the current comparative fault defense scheme and explaining that it is necessary to recognize that victims should not be required to tailor their conduct to the risk of violent crime); Ellen M. Bublick, Comparative Fault to the Limits, 56 VAND. L. REV. 977, 978-81 (2003) (advocating limits on plaintiff fault defenses).

140 See Bublick, supra note 20, at 1416.

141 See discussion infra notes 154-57 (tracing the enterprise liability theme in the deterrence and faimess rationales for vicarious liability).
} 
deterrence rationale for imposing vicarious liability remains strong, regardless of how victim fault is ultimately handled.

\section{B. The Fairness Case for Vicarious Liability}

In the U.S. academic literature, the fairness rationale for vicarious liability is not as well developed as the deterrence/efficiency rationale. ${ }^{142}$ However, similar to the deterrence rationale for vicarious liability, the fairness case for vicarious liability starts from the proposition that he who creates the risk should bear the loss. ${ }^{143}$ Put in slightly different terms, the argument is that when an enterprise introduces a risk into the community it should accept responsibility for managing the risks it has created. In an important article, Gregory Keating emphasized that Judge Friendly's iconic opinion in Bushey ${ }^{144}$ was predicated not on efficiency or economic rationales, but on a principle of fairness, namely, "in a deeply rooted sentiment that a business enterprise cannot justly disclaim responsibility for accidents which may fairly be said to be characteristic of its activities." 145 Keating argued that "there is a powerful and important fairness case to be made for enterprise liability," including the principle of employer vicarious liability so firmly established in the law. ${ }^{146}$ In Keating's view, the emphasis on optimal deterrence in the economic literature "slights the sense of justice that lies behind enterprise liability," 147 a sense of justice often expressed by courts if not by commentators. For Keating, imposing strict liability on enterprises is fair regardless of its capacity to deter or prevent injuries because, in the modern world, injuries are the "inevitable by-products of planned activities - not the random consequences of discrete acts." 148 It is this very fact that risks created by enterprises are "recurrent and related" that makes it fair to impose strict liability. ${ }^{149}$ Keating thus draws a sharp contrast between negligence and strict liability. He theorizes that negligence deals with liability for unreasonably imposing a risk, while

142 Gregory C. Keating, The Idea of Fairness in the Law of Enterprise Liability, $95 \mathrm{MICH}$. L. REV. 1266, 1270 (1997). Keating complains that law and economics scholarship has dominated the academic writing on enterprise liability and that many corrective justice scholars avoid the subject because they view enterprise liability with suspicion. Id.

143 Id. at 1269.

144 Ira S. Bushey \& Sons, Inc. v. United States, 398 F.2d 167, 168 (2d Cir. 1968); see supra text accompanying notes 85-90 (discussing Judge Friendly's opinion in Bushey).

145 Keating, supra note 142, at 1379 (quoting Bushey, 398 F.2d at 171) (internal quotation marks omitted).

146 Id. at 1266.

147 Id. at 1267.

148 Id.

149 Id. at 1273. 
strict liability deals with liability "for unreasonably failing to accept financial responsibility for a harm that issued from a reasonable risk." 150

Under the fairness rationale, vicarious liability is tied to proper risk management. ${ }^{151}$ Particularly because enterprises are in a better position to spread the losses among their customers or beneficiaries, and often profit from their activities, it is fair for the enterprise to provide compensation rather than impose the loss on the individual victim. ${ }^{152}$ In this respect, vicarious liability fits well alongside the regime of worker's compensation. In the modern world, where the costs of injuries to employees are properly regarded as a charge of the enterprise when caused by fellow employees, there is little warrant for classifying injuries to customers, clients, patients, or other victims any differently when caused by that same group of employees. ${ }^{153}$

What is significant about both the efficiency and fairness justifications for vicarious liability is their dependence on a notion of enterprise causation. Although its function differs under each theory, enterprise causation is central to both arguments. For economic scholars, enterprise causation sets the basic framework for determining optimal deterrence. ${ }^{154}$ It triggers the need to determine which allocation of loss among the parties will best promote efficiency. ${ }^{155}$ In accounts centered on fairness, enterprise causation marks out the limit of liability, setting the boundary of vicarious liability and the employer's responsibility at the point "where an enterprise ceases to create risks different from those occasioned by the ordinary life of the community."156 In the fairness account, unless the enterprise poses a "distinctive risk" above and beyond the background level of risk that would be present even absent the employment relationship, it is considered unfair to impose liability on the employer. ${ }^{157}$ Notably, in each of these accounts, the crucial starting point for analysis is the enterprise, rather than the individual actor, a reflection of the fact that modern-day vicarious liability is centrally concerned with the liability of enterprises and institutions.

With their emphasis on enterprise causation, the rationales for vicarious liability found in the academic literature match up well with

\footnotetext{
$150 \quad$ Id. at 1276.

151 See Brodie, supra note 19, at 495-96.

152 See Steven N. Bulloch, Fraud Liability Under Agency Principles: A New Approach, 27 WM. \& MARY L. REV. 301, 306 (1986) (discussing the loss spreading rationale for vicarious liability).

153 ATIYAH, supra note 8, at 24.

154 ChAMALLAS \& WRIGGINS, supra note 116, at 14.

155 Id.

156 Keating, supra note 142, at 1277.

157 Id. at 1291-92.
} 
the more liberal tests for vicarious liability centered on enterprise risk and foreseeability. Tellingly, neither of the two contemporary rationales for vicarious liability leads to an inquiry into the offending employee's motivation and thus provides little or no support for retaining the "motive to serve" test. 158 Instead, the "motive to serve" test is more in line with an antiquated view of vicarious liability, which conceptualizes the employer as an individual-rather than an entity-and attempts to explain why one individual should be held responsible for another individual's actions. From this perspective, the "motive to serve" test links to a very old, and very outdated, hostility toward paid employment that once held that, in an ideal world, people should do their own work.159 Atiyah explains that, in this view, "[i]t is only by [the] indulgence of the law that [individuals] are allowed to employ others to do the work for them, and [that] part of the price they have to pay for this indulgence is to accept liability for the servant's acts." 160 In this highly individualistic narrative, the primary function of vicarious liability is to tie an individual employee's acts to his (individual) employer's desires and interests, in a kind of meeting of the minds between principal and agent. This view also tends to place the employer and employee on an equal footing and looks to see whether the motivation of one individual mirrors or mimics the other. Now that we no longer regard employment as an indulgence, and recognize the significant asymmetries between institutional employers and individual employees, there is no need to insist that, before we impose liability, the employee understand his action as an action taken on behalf of another individual with a motive to serve that other person's interests.

As mentioned earlier, the modern rationales for vicarious liability were developed with employee negligence in mind and have persuaded courts to apply vicarious liability as a routine matter when employees cause harm through their negligence and in many instances of nonsexual intentional torts. ${ }^{161}$ Yet, these rationales have tended to dissipate or even disappear when U.S. courts confront cases of sexual abuse and

\footnotetext{
158 Proof that a tort arguably furthered the employer's interests may be relevant to an assessment of "enterprise causation" insofar as it increases the chances that employeeswho have a built-in incentive to act in a way that furthers their employer's mission - will be more likely to engage in such conduct. This probabilistic argument, however, does not turn on the employee's motivation to serve the employer's interest and operates only as one factor in determining whether the enterprise "materially enhanced" the risk of the abuse. See Sykes, supra note 19, at 571-81 (discussing causation issues and various approaches to employer liability).

159 ATTYAH, supra note 8, at 21.

160 Id.

161 See supra Part II.C (discussing judicial treatment of vicarious liability in non-sexual intentional tort cases).
} 
exploitation. ${ }^{162}$ What is it then that makes courts so resistant to imposing vicarious liability in sexual misconduct cases? What is missing from the standard arguments for vicarious liability that might convince courts to extend vicarious liability to these cases?

\section{INTERDISCIPLINARY INSIGHTS: FEMINISM, COGNITIVE PSYCHOLOGY, AND INSTITUTIONAL CULTURE}

To supply the missing arguments, it is useful to step back from legal doctrine and mainstream legal theory and draw upon knowledge from interdisciplinary sources-most prominently feminist theory, cognitive psychology, and scholarship on institutional culture - to understand the exceptional treatment of sexual misconduct cases in vicarious liability law. Because the case law and the academic torts literature have not supplied a sufficient explanation why sexual misconduct is so often treated differently, it is necessary to search for deeper roots for the sex exception to vicarious liability. Each of the interdisciplinary sources discussed in this section leads us to mistrust the sharp distinction between sexual and other misconduct that characterizes the law of vicarious liability and suggests that the sex exception should be reexamined.

Following the thread of the academic torts literature, it makes sense to build from the foundation of enterprise risk and enterprise causation and to accept that vicarious liability should be imposed only for those risks created by or caused by the enterprise. Thus, the ability to establish a nexus between the enterprise (or institution) and the risk becomes the fundamental step in the analysis. However, it is important to recognize is that taking this crucial step involves more than value-free description. As one British commentator has pointed out, identifying the risks of an enterprise is "very much a value judgment; it is a matter of what 'experience shows."'163 If one's experience or judgment leads to the conclusion that sexual conduct is unique, bearing no connection to other aspects of life, such as employment, it will be very difficult to regard employee sexual abuse as "engendered by" or "arising out of" employment. But if one's experience or judgment leads to the conclusion that engaging in sexual conduct is often opportunistic, and that it can be facilitated or inhibited in certain settings, it is a much smaller step to regard sexual abuse as job-related.

${ }^{162}$ See supra Parts II.A-B (providing examples of sexual abuse cases in which courts refused to impose vicarious liability).

163 Brodie, supra note 19, at 498. 


\section{A. Feminist Theory and Sexual Exceptionalism}

At this point, the voluminous feminist literature on sexual abuse has much to offer. Feminists have long resisted sexual exceptionalism, by which I mean the tendency to characterize sexual desire or motivation as different from all other inducements to action. ${ }^{164}$ Well beyond the confines of vicarious liability doctrine, feminists have registered objections to two fundamental and interrelated flaws in this traditional approach to sex and sexual abuse: first, they object to the tendency to lump together virtually all forms of sexual conduct, regardless of its abusive or harmful nature; and second, they take issue with the tendency to classify sexual conduct as unique behavior propelled exclusively by private (mostly physical) desires and urges. ${ }^{165}$

In the United States, feminist resistance to sexual exceptionalism first found concrete expression in early debates over rape and workplace sexual harassment. ${ }^{166}$ In these contexts, feminists contested traditional views of sexual conduct that had failed to distinguish between coercive forms of sexual behavior and consensual or mutual sex. ${ }^{167}$ Such conflation of sexual abuse and consensual sex meant that sexual conduct, regardless of its harmful quality, was often exempt from legal penalties, with a corresponding lack of protection for victims of sexual abuse. ${ }^{168}$ To counter this tendency, many feminists argued that rape should be approached like other forms of criminal physical violence, ${ }^{169}$ and that sexual harassment was a form of sex discrimination that deprived women of job opportunities and advancement, much like denials of equal pay or promotions. 170 The key strategic move here was to reveal and to emphasize the similarities among sexual and non-sexual forms of violence and discrimination in an attempt to demonstrate that not all

\footnotetext{
164 Adrienne D. Davis, Bad Girls of Art and Law: Abjection, Power, and Sexuality Exceptionalism in (Kara Walker's) Art and (Janet Halley's) Law, 23 YALE J.L. \& FEMINISM 1, 47 (2011).

165 See discussion infra Part IV.A (discussing major feminist criticisms of traditional approaches to sexual abuse).

${ }_{166}$ See MARTHA Chamallas, INTRODUCTION TO FEMINIST LeGAL THEORY 58-59 (3d ed.

2013) (describing the early feminist debate over sexual harassment and rape).

167 Id. at 59.

168 Id.

169 See ANN J. CAHILL, RETHINKING RAPE 2 (2001) (discussing the "violence, not sex" school of feminist philosophy generated by Susan Brownmiller's famous book Against Our Will: Men, Women, and Rape); see also Martha Chamallas, Lucky: The Sequel, 80 IND. L.J. 441, 444, 461 (2005) (discussing how feminist activists have tried to sever the connection between rape and sex).

170 For examples of two highly influential books, see LIN FARLEY, SEXUAL SHAKEDOWN: THE SEXUAL HARASSMENT OF WOMEN ON THE JOB 14-15 (1978); CATHARINE A. MACKINNON, SEXUAl HARASSMENT OF WORKING WOMEN: A CASE OF SEX DisCRIMINATION 208 (1979).
} 
sexual conduct should be lumped together and treated as sui generis, as either a social good or the inevitable outcome of (hetero)sexual attraction. ${ }^{171}$

The push against sexual exceptionalism can be seen most prominently in the feminist campaign in the 1970s to reform traditional rape laws. Prime targets of reform were special requirements that applied only to rape cases, thus marking out sexual violence as exceptional and warranting extreme caution in prosecutions of suspected rapists. ${ }^{172}$ In this period, feminists successfully fought for repeal of cautionary instructions that warned juries to be skeptical of rape charges, ${ }^{173}$ prompt complaint requirements that barred prosecutions if victims did not report the offense shortly after being victimized, ${ }^{174}$ and corroboration requirements that required evidence beyond the victim's word that an offense had occurred.175 Additionally, burdensome "consent" standards that required proof of physical resistance by the victim were revised to conform more closely to definitions of other violent crimes that did not presume consent from silence or lack of resistance. ${ }^{176}$ Each of these reforms was also designed to make inroads in

171 It should be noted that same-sex sexual conduct was never immunized and was subject to harsh penalties under a traditional view of sexual conduct that regarded homosexual behavior as illicit, whether coercive or consensual. See Martha Chamallas, Consent, Equality, and the Legal Control of Sexual Conduct, 61 S. CAL. L. REV. 777, 784-85 (1988). Predictably, the early debates over sexual harassment presupposed a male perpetrator and a female victim, a heterosexist presumption that largely eclipsed same-sex sexual harassment and centered the debate on male heterosexual desire.

172 See Aya Gruber, Rape, Feminism, and the War on Crime, 84 WASH. L. REv. 581, 593 (2009) (discussing legal barriers, such as resistance and corroboration requirements, which differentiated rape from other crimes).

173 Many states gave instructions similar to Chief Justice Matthew Hale's warning that "Rape... is an accu[s]ation ea[s]ily to be made and hard to be proved, and harder to be defended by the party accu[s]ed, tho never so innocent." MATTHEW HALE, THE HISTORY OF THE PLEAS OF THE CROWN 634 (E. Rider, Little-Britain, 1800).

174 Vivian Berger, Man's Trial, Woman's Tribulation: Rape Cases in the Courtroom, 77 COLUM. L. REV. 1, 10 n.72 (1977) ("In some schemes, this permissive evidentiary practice [regarding prompt complaints] has been transformed into a mandatory rule of law: a form of statute of limitations."); Leigh Bienen, Rape III-National Developments in Rape Reform Legislation, 6 WOMEN'S. RTS. L. REP., Spring 1980, at 170, 175 (1979-1980) ("[T]he prompt complaint requirement ... w [as] [a] Model Penal Code provision which w[as] incompatible with the goals of feminists lobbying for rape reform legislation.").

175 Berger, supra note 174, at 9 ("[T] rape victim; it must produce some other evidence tending to support its case. .. . [and] may have to corroborate each material element of the crime or only some particular aspect of the prosecutrix's story." (footnote omitted)).

176 Chamallas, supra note 171, at 799-800. The elimination of the physical resistance requirement was just the first step in reforming the legal definition of "consent" in rape laws. See CHAMAlLAS, supra note 166, at 291-95 (describing a move to eliminate the "external force" requirement and adopt an affirmative consent standard). 
the one-sided way the law approached sexual violence by moving the legal doctrine away from embracing the perspective of the perpetrator (who tended to label the event as "sex") to acknowledging the perspective of the victim (who more often regarded the event as "violence"). The net effect of these reforms, while proving to be no panacea for eliminating sexual violence, was to modify the de facto legal immunity given to many forms of sexual violence and to afford some assurance that rape would no longer be exempt because "[i]t is the only crime of violence that masquerades as sex."177

Most important for our purposes, also starting in the 1970s, a new consciousness developed about the phenomenon of workplace sexual harassment. ${ }^{178}$ Early cases had dismissed sexual harassment claims as essentially private disputes that bore little relationship to employmentrelated injuries, such as lack of equal pay or failure to promote. ${ }^{179}$ The courts' negative response stemmed from the belief that harassers were motivated to act out of sexual desire for a particular woman and that their conduct was fundamentally about sex, not work. ${ }^{180}$ In an effort to reclassify sexual harassment as "discrimination" rather than "sex," employees, legal advocates, and social activists began to document that sexual harassment had much the same effect as other forms of workplace discrimination - namely, to retard women's advancement on the job and to reinforce gender segregation. ${ }^{181}$ By the 1980 s, it was clear that sexual harassment was not just a personal problem faced by individual women but a systemic harm that a high percentage of women would confront over the course of their working lives. ${ }^{182}$

When the Supreme Court finally recognized the hostile work environment claim in 1986,183 it had little difficulty rejecting the

\footnotetext{
177 NANCY VENABLE RAINE, AFTER SILENCE: RAPE AND MY JOURNEY BACK 225 (1998).

178 CHAMALLAS, supra note 166 , at 58.
}

179 See, e.g., Tomkins v. Pub. Serv. Elec. \& Gas Co., 422 F. Supp. 553, 557 (D.N.J. 1976) (holding that no discrimination occurred because the conduct stemmed from "natural sexual attraction"); Corne v. Bausch \& Lomb, Inc., 390 F. Supp. 161, 163 (D. Ariz. 1975) (holding that the harasser's conduct was "nothing more than a personal proclivity, peculiarity or mannerism. ... [that] satisf[ied] a personal urge").

180 See cases cited supra note 179.

181 See CHAMALlas, supra note 166, at 59 (discussing the feminist argument that "[b]ecause sexual harassment was a central mechanism for perpetuating women's inferior status in the workplace, it ought to be regarded as sex discrimination"); supra text accompanying note 170 (analogizing sexual harassment to denials of equal pay or promotions).

182 See BARBARA LINDEMANN \& DAVID D. KADUE, SEXUAL HARASSMENT IN EMPLOYMENT LAW 4-5 (1992) (reviewing empirical studies of sexual harassment in the workplace).

${ }_{183}$ See Meritor Sav. Bank v. Vinson, 477 U.S. 57, 65-66 (1986) (endorsing the EEOC Guidelines on sexual harassment, codified at 29 C.F.R. $\$ 1604.11(a)(2013)$ ). The EEOC 
traditional view that regarded a supervisor's sexual propositioning or sexual coercion of an employee as personal and unrelated to the employer's business, simply because it might be said to be driven by the harasser's sexual attraction to the plaintiff. In this way, the Court no longer treated sexual conduct as qualitatively different from other forms of worker abuse. Instead, by focusing on the effects of the harasser's action on the plaintiff and her co-workers, the Court de-privatized the injury of sexual harassment and located it squarely within the realm of the workplace. ${ }^{184}$ The entire body of sexual harassment law is premised on the view that solicitations for sex and other sexualized conduct in the workplace can produce harm and should not be dismissed as harmless flirtations or the inevitable fallout of mixing the sexes at work. Catharine MacKinnon, one of the principal architects of sexual harassment law, has described the change that took place in the Title VII sexual harassment law as a paradigm shift that transformed the cultural understanding of sexual harassment "from private joke to public weapon." 185

Supporting the judicial recognition of the claim, feminist scholars supplied new accounts of the nature and causes of sexual harassment that downplayed the role of the perpetrator's sexual desire and sexual attraction. These scholars argued that sexual harassment was not simply the byproduct of sexual desire directed at a particular target but often functioned to serve other purposes as well, for example, to perpetuate gender segregation in the workplace or to preserve male control of certain lines of work. ${ }^{186}$ In some hostile environment cases, for example, the harassers may have no interest at all in sexual gratification, but simply use sexually charged language or sexually aggressive conduct as a weapon to enhance their own standing or control at work. Even in cases of sexual propositioning or sexual touching, the new scholarly accounts teased out the "mixed motive" nature of much of the sexual

Guidelines regarding sexual harassment have exerted a huge influence on written employer policies against sexual harassment.

184 Id. at 66-67 (analogizing the effects of sexual harassment to those of racial discrimination in the workplace).

185 Catharine A. MacKinnon, The Logic of Experience: Reflections on the Development of Sexual Harassment Law, 90 GEO. L.J. 813, 831 (2002).

186 See Kathryn Abrams, The New Jurisprudence of Sexual Harassment, 83 CORNELL L. REV. $1169,1196-98$ (1998) (discussing assertions of male control in the workplace and explaining that instances of sexual harassment against women "have the goal and, inevitably, have the effect of preserving male control and masculine norms that have characterized the workplace"); Vicki Schultz, Reconceptualizing Sexual Harassment, 107 YALE L.J. 1683, 1759 (1998) ("For many, if not most, women workers, neither sexual desire nor sexual advances are the core of the problem. Where sexual misconduct occurs, it is typically part of a broader pattern of harassment designed to reinforce gender difference and to claim work competence and authority as masculine preserves." (footnote omitted)). 
behavior that commonly occurs at work, arguing that the sexual nature of verbal and physical conduct should not eclipse the power dynamics also in play. ${ }^{187}$

Moreover, by the 1990s, after the phenomenon of same-sex sexual harassment became more visible, there was a growing recognition that many victims of sexual harassment were male and that sexual harassment also occurred in all-male workplaces. ${ }^{188}$ The harassers in these same-sex incidents were often heterosexual men who used sexual harassment as a tool to police gender norms at their workplace and to ensure that any man who did not conform to their image of a "real $\mathrm{m}[\mathrm{a}] \mathrm{n}$ " was penalized. ${ }^{189}$ Particularly in the same-sex context it was hard to insist that workplace sexual conduct was simply a manifestation of lust and desire in cases in which there was little evidence that the perpetrators were gay or bisexual. ${ }^{190}$

Alongside the discovery of the multiple causes of sexual harassment came the realization that for victims of both genders, sexual harassment was not a trivial harm, but was qualitatively different from teasing, sexual banter, or horseplay. ${ }^{191}$ This perspective contrasts sharply with some of the portrayals of sexual behavior in tort cases. For example, the Supreme Court of Missouri in 1997 declined to impose liability on a diocese when a priest invited a boy to "spend the night and watch movies" at the church rectory and then fondled the boy in a sexual manner. ${ }^{192}$ To avoid liability, the diocese minimized the harm, brushing off the incident as just "an innocent pat on the butt," something "that happens to young men all the time," and something that the boy "would [soon] get over."193 Coming to grips with the sexual abuse of men and boys apparently continues to be difficult for those who believe that men by their nature want and desire sex in any setting-no matter how coercive - and are not really harmed by sexual behavior. ${ }^{194}$

187 E.g., Martin J. Katz, Reconsidering Attraction in Sexual Harassment, 79 IND. L.J. 101, 143 (2004).

188 See Oncale v. Sundowner Offshore Servs., Inc., 523 U.S. 75, 79-80 (1998) (holding that Title VII protects individuals from all types of sexual harassment in the workplace, including male-on-male sexual harassment).

189 Katherine M. Franke, What's Wrong with Sexual Harassment?, 49 STAN. L. REv. 691, 696, 770 (1997).

190 See Oncale, 523 U.S. at 80 ("But harassing conduct need not be motivated by sexual desire to support an inference of discrimination on the basis of sex.").

191 See Faragher v. City of Boca Raton, 524 U.S. 775, 787-88 (1998) (distinguishing between actionable sexual harassment and simple teasing and joking).

192 Gibson v. Brewer, 952 S.W.2d 239, 243, 246 (Mo. 1997).

193 Id. at 243 (internal quotation marks omitted).

194 See Kim Shayo Buchanan, Engendering Rape, 59 UCLA L. REv. 1630, 1649 (2012) ("[C]onventional gender expectations, ... might suggest that men want sex with women in 
One central tenet of much of the feminist literature in this area is that sex is not divorced from power, including the power conferred through the employment relationship. ${ }^{195}$ For over a generation, feminist legal reformers have insisted that institutional sexual abuse is not just a manifestation of lust, sexual desire, or sexual attraction, 196 the vocabulary we generally associate with consensual sexual relations in the private sphere. Instead, by introducing the victim's perspective into the law, sexual conduct that was once immune from legal penalties was redefined as injury, even when the perpetrator was motivated in part by sexual desire. It was thus no longer anomalous to speak of job-created power as a cause of sexual injury, forging an important link between employment and sex.

This is not to say that traditional views of sexual conduct no longer influence Title VII sexual harassment law. Indeed, some courts still characterize sexual propositioning and other sexual conduct as conduct arising from private sexual desire and then go on to the rule that such behavior does not qualify as sex discrimination within the scope of Title VII. ${ }^{197}$ A more complete picture of Title VII law recognizes that new and old conceptions of sexual behavior compete for acceptance, a competition that lends some instability to the law but is not surprising given the sharp cultural divide in our society.

For the most part, however, the feminist insights and innovations with respect to sexual conduct and employment that proved crucial to the early development of Title VII law have not carried over into tort law to guide courts' analyses in vicarious liability cases. Instead, many of the tort cases denying vicarious liability for employee sexual abuse use the same language and reasoning found in the early sexual harassment cases decided before recognition of the sexual harassment cause of action. It is true that, like Title VII law, the body of tort law is not uniform. Likely influenced by Title VII developments, some courts in the 1980s and early 1990 s focused on the element of "job-created power" as a reason to

virtually any circumstances, and that heterosex cannot harm them."); Marc Spindelman, Sexual Freedom's Shadows, 23 YALE. J.L. \& FEMINISM 179, 250 (2011) (arguing that coercive intercourse is so normalized among gay men that "it's often seen as simply sex").

195 See CHAMALLAS, supra note 166, at 309-33 (discussing sexual harassment litigation and feminist literature treating sexual harassment as an aspect of the sexual subordination of women); see also Brianna J. Schroeder, Note, Power Imbalances in College Athletics and an Exploited Standard: Is Title IX Dead?, 43 VAL. U. L. REV. 1483, 1513-20 (2009) (discussing the role of power imbalances in sexual harassment occurring in student athletic settings).

196 The argument was first articulated by Catharine MacKinnon. See MacKinnon, supra note 170 , at 32 .

197 See, e.g., Nelson v. James H. Knight, DDS, P.C., 834 N.W.2d 64, 67, 73 (Iowa 2013) (holding that no discrimination occurred when an employer fired a female employee due to his wife's fear that he was sexually attracted to the employee). 
impose vicarious liability in tort sexual abuse cases. ${ }^{198}$ However, this trend has largely stalled out, with many courts again becoming preoccupied with ferreting out the offending employee's motive or being simply content to treat sexual abuse different from other forms of intentional misconduct. ${ }^{199}$ The competition between old and new conceptions of sexual conduct found in the Title VII cases is not as visible in contemporary tort cases, leaving the (mis)impression that the traditional view of sex as exceptional is undisputed.

The feminist critique of sexual exceptionalism is largely a structural analysis that emphasizes the relative power and social position of the actors. In this account, an employee's position in the employment hierarchy - as well as his gender or other marker of privileged identity is seen as integral to his ability to harass or abuse a less-powerful individual. ${ }^{200}$ The all-important connection to employment is supplied by the employer's decision to cloak the employee with power or authority over others. This critique fits comfortably with the enterpriserisk rationale for vicarious liability. What distinguishes the feminist accounts from the "enterprise causation" theories in the mainstream academic literature, however, is the specific identification of sexual abuse as one of the recurring risks of enterprises. The feminist critique thus supplies a potent argument for extending vicarious liability to this type of harm as well.

\section{B. Cognitive Psychology}

Given its genesis in the late 1970 s and early 1980s, the feminist critique of sexual exceptionalism is by now old news. To understand why it has not had more influence on tort law, we need to consult a different body of interdisciplinary scholarship that focuses on habitual ways of thinking and provides a clue to the resiliency of the sex exception, despite its inconsistency with both mainstream and feminist theoretical approaches. In contrast to the structuralist arguments discussed above, cognitive psychology focuses on processes of individual decision-making, including decisions relating to causation. ${ }^{201}$ Cognitive psychology explains why, for example, intuitive causal

\footnotetext{
198 See Weber, supra note 9 , at 1522 \& n.35 (discussing cases that focus on job-related power or authority).

199 See supra Parts II.A, C (discussing the focus on employee motive and the exceptional treatment sexual torts receive compared to non-sexual intentional torts).

2000 See Katherine Roush, Let's Talk About Sex Discrimination: The Tenth Circuit's Decision in Dick v. Phone Directories Co., 83 DENV. U. L. Rev. 719, 721 (2006) (discussing gender hierarchy within the workplace).

201 CHAMALLAS \& WRIGGINS, supra note 116, at 124-28 (discussing psychological approaches to questions of legal causation).
} 
judgments made by both experts and lay people may be systematically flawed and impervious to contradictory evidence. In the context of vicarious liability, it provides a reason why courts might be drawn to outdated portrayals of employee sexual misconduct as manifestations of lust, desire, or individual proclivity, even when those decision-makers no longer subscribe to a traditional ideology that distrusts victims' accounts of sexual injury and minimizes the harm of abusive sexual conduct.

Looking at the sex exception from a psychological standpoint, the reluctance to impose vicarious liability for sexual misconduct may be traced to what cognitive psychologists call the "fundamental attribution error," a common cognitive bias that comes into play whenever people make judgments about cause and effect. ${ }^{202}$ Recall that the central question underlying vicarious liability is whether sexual misconduct is "engendered" by, or is a "characteristic risk" of, the business, making us ask whether the employment of the offender caused the victim's harm. ${ }^{203}$ Psychologists tell us that the process by which people draw conclusions about cause and effect is not one of passive discovery of objective fact but consists of an active process of causal attribution. ${ }^{204}$ Boiled down to a basic choice, courts in sexual misconduct cases are asked to decide whether to attribute the sexual injury to the offender or to the enterprise. Although the doctrine of vicarious liability allows imposition of liability on both potential defendants (via vicarious liability for the employer and intentional tort liability for the employee), when causal judgments are required, the opportunity for bias in causal attributions occurs regardless of the specifics of the legal doctrine. ${ }^{205}$

Cognitive psychologists explain that people typically interpret events in one of two ways: either they believe that the event is caused by something having to do with the character or personality traits of the individual actor (the "dispositional" explanation); or they attribute the result to forces outside the actor, focusing on the environment or the situation in which the event takes place (the "situational" explanation). ${ }^{206}$

\footnotetext{
202 See Adam Benforado \& Jon Hanson, Attributions and Ideologies: Two Divergent Visions of Human Behavior Behind Our Laws, Policies, and Theories, in IDEOLOGY, PSYCHOLOGY, AND LAW 298, 299 (Jon Hanson ed., 2012) (describing the "fundamental attribution error" as "the tendency to attribute to the person what is often the consequence of the person's exterior situation").

203 See supra Part II.B (discussing the foreseeability and "enterprise risk" tests).

204 Chamallas \& WRIGGINS, supra note 116, at 124.

205 Linda Hamilton Krieger, The Content of Our Categories: A Cognitive Bias Approach to Discrimination and Equal Employment Opportunity, 47 STAN. L. REv. 1161, 1204-07 (1995) (discussing biases in causal attribution and the effect of such biases in the employment context).

206 Benforado \& Hanson, supra note 202, at 298.
} 
The fundamental attribution error is the tendency to attribute an event to the character or disposition of the individual actor and to miss the significance or underplay the contribution of situational factors. ${ }^{207}$ In the vicarious liability context, the offending employee is the actor upon which attention is likely to be focused, while the employer is cognitively associated with background situational forces. The fundamental attribution error thus operates to shine a spotlight on the character of the offending employee, while underplaying the contribution of the employer.

The source of the fundamental attribution error is still being debated. Some theories stress that it is the salience of an individual actor that captures our attention, as compared to the muted background factors that do not stand out in memory or perception. ${ }^{208}$ Other theories explain that the preference for dispositional attributions comes from our desire to believe that we live in a "just world," in which people get what they deserve and act according to a predictable script. ${ }^{209}$ In this motivational account of the fundamental attribution error, it is comforting psychologically to attribute failures (and injuries) to dispositional causes over which we tend to have more control, rather than to situational causes that seem more random and uncontrollable. 210 Regardless of its source, however, it is agreed that the fundamental attribution error is a settled psychological insight that likely affects legal judgments about causation. 211

This tendency to fixate on the psychological makeup of the actor provides a good explanation for courts' readiness to attribute sexual misconduct on the job to the sexual proclivities, sexual desires, or lust of the offender, while missing the importance of situational factors, such as the offender's status or position at work and the nature of the job. When a plaintiff charges that he or she has been molested by an employee of a business or institution, it is understandable that our attention would focus on the individual perpetrator's character or disposition, rather than

207 Krieger, supra note 205, at 1204-05.

208 See Susan K. Green et al., A General Model of the Attribution Process, 6 BASIC \& APPLIED SOC. PSYCHOL. 159, 160 (1985) ("[W]here less information is available, the attribution outcome depends on whether a person schema or normative script is most salient for the observed behavior and whether that behavior is expected or unexpected.").

${ }_{209}$ Jon Hanson \& David Yosifon, The Situation: An Introduction to the Situational Character, Critical Realism, Power Economics, and Deep Capture, 152 U. PA. L. REV. 129, 147 (2003); Jon Hanson \& David Yosifon, The Situational Character: A Critical Realist Perspective on the Human Animal, 93 GEO. L.J. 1, 102 (2004).

210 Adrian Furnham, Belief in a Just World: Research Progress Over the Past Decade, 34 PERSONALITY \& INDIVIDUAL DIFFERENCES 795, 796 (2003).

211 Benafardo \& Hanson, supra note 202, at 299 (noting that the "fundamental attribution error" is "among the most settled of social psychological insights"). 
the features of the job that facilitated the abuse. It is as if the (possible) presence of individual sexual desire overwhelms or overshadows other factors. Particularly when one considers that abusive sexual conduct has long been assimilated to consensual sex, and thus seems "like sex" in this respect, the tendency to focus on the sexual desire of the individual employee can be appreciated as a familiar move that occurs without much conscious thought.

Likely exacerbating this tendency to link sexual misconduct to the pre-existing disposition of the offender, rather than seeing it as an "outgrowth" of the job, is another common cognitive bias: the preference for simple causal explanations. Research indicates that people prefer simple explanations to complex ones, with the consequence that people are often "content to rely on what first strikes them as a plausible sufficient cause for an event," even when other plausible causes exist. ${ }^{212}$ This bias toward monocausality eclipses the possibility of alternative explanations for an event and pushes mixed motivation cases out of view. ${ }^{213}$ Mimicking the fundamental attribution error, which privileges dispositional explanations over situational ones, the bias toward monocausality reinforces either/or thinking. In the vicarious liability context, this means that if the offending employee's personal desire for sex plausibly explains his sexual misconduct, we are not inclined to inquire further and seek out additional equally plausible situational causes for the injury. Moreover, rather than seeing sexual misconduct cases as arising both from the personal predilections of the offender and from his employment, some courts may view sexual misconduct as private and personal only, never pausing to consider the mixed motive explanation. This tendency reinforces the cognitive separation between sex and employment, even though we now know that much sexual misconduct arises at work. It also helps to explain some puzzling features of the case law: it offers a reason, for example, why courts applying the "motive to serve" test may fail to classify sexual behavior as stemming from mixed motives that serve the interests of both the employee and the employer; ${ }^{214}$ or why courts applying the "enterprise risk" standard would nevertheless classify sexual

212 NeIL FEIGENSON, Legal BlamE: How JURORS THINK AND TALK ABOUT ACCIDENTS 51$52(2000)$.

213 Martha Chamallas, Deepening the Legal Understanding of Bias: On Devaluation and Biased Prototypes, 74 S. CAL. L. Rev. 747, 782 (2001); see CHAMALLAS \& WRIGGINS, supra note 116, at 125 (discussing the preference for "one-cause explanation[s]").

214 See, e.g., Buck v. Blum, 130 S.W.3d 285, 289-90 (Tex. App. 2004) (holding that there was no vicarious liability as a matter of law when a neurologist sexually assaulted his patient during the course of an examination because the "action was [not] in furtherance of the employer's business"). 
misconduct as unforeseeable or unexpected, despite its prevalence in the workplace. ${ }^{215}$

Taken together, the fundamental attribution error and the bias toward monocausality help explain a paradox in the U.S. vicarious liability case law: while courts profess egalitarian views, condemn sexual misconduct in strong terms, and seem to appreciate its harms, they nonetheless continue to employ an implicit causal theory of sexual misconduct in the workplace befitting a pre-feminist world where sexual conduct was viewed as private behavior having nothing to do with the public sphere of work and employment. While it does not constitute an independent rationale for imposing vicarious liability in the employment context, cognitive psychology provides an additional ground for questioning courts' reluctance to find the requisite causal link to employment in employee sexual misconduct cases.

\section{Institutional Culture}

Finally and relatedly, recent interdisciplinary scholarship focusing on institutional culture offers a new way of thinking about some of the issues embedded in vicarious liability cases and raises additional questions about the sex exception to vicarious liability. This strand of critical theory highlights the importance of "framing" in selecting certain injuries for compensation. ${ }^{216}$ Margaret Hall, a Canadian critical theorist who writes about sexual abuse in children's residential homes and other institutional settings, has argued for a re-framing or re-conceptualization of vicarious liability, making the case for a paradigm shift in the images we use to explain vicarious liability and sexual misconduct. 217 Hall maintains that there is a crucial "gap between the 'real' and understood world" that affects legal remedies for sexual abuse as well as extralegal methods of preventing sexual abuse.218 For Hall, the dominant images that circulate in and drive legal discourse do not match up to the reality of sexual abuse in institutional settings. This mismatch sets up the law to fail as a means of addressing and redressing the sexual violation of children in residential care.

215 See, e.g., Lisa M. v. Henry Mayo Newhall Mem'l Hosp., 907 P.2d 358, 359, 365, 367 (Cal. 1995) (refusing to impose vicarious liability on a hospital where a medical technician molested a nineteen-year-old pregnant woman during an ultrasound because the assault was "not a generally foreseeable consequence" of the contact).

216 For a discussion of the importance of framing in the development of tort law, see Timothy D. Lytton, Clergy Sexual Abuse Litigation: The Policymaking Role of Tort Law, 39 CONN. L. REV. 809, 818-22 (2007).

217 Hall, supra note 19 , at 160.

$218 \quad$ Id. at 161. 
As Hall sees it, the conventional understanding of the abuse of children in institutional care envisions a pathological outsider infiltrating an otherwise healthy system. In this "honeypot" conceptualization of the problem, certain personality types (e.g., bullies, predators, and pedophiles) are "drawn to child care institutions like the proverbial bee to the honey pot."219 Another Canadian commentator has used a similar image, imagining a bakery that attracts rats to the neighborhood.220 In this imagery, the bee or rat is inevitably and naturally drawn to the source of their desire and invades from the outside. Of course, in the real-world vicarious liability context, the offending employee is already a part of the enterprise. Framing the offender as an "outsider," even though he or she is already part of the enterprise or institution, is the crucial conceptual move here.221 Once this image and conceptualization of the problem takes hold, the sole goal becomes keeping the outsider "out." Hall argues that under this conventional image, the institution is seen as being duped by the offender, and as such, it appears as an "outraged innocent, alongside the violated child."222

Hall forcefully argues that, for many institutions, this picture is inaccurate and misleading. ${ }^{223}$ The first-hand accounts of institutional abuse (think: the Catholic Church or the Boy Scouts) suggest that certain institutions foster or even create abusers and that certain institutional conditions tend to produce abusive behaviors in otherwise normal adults. ${ }^{224}$ The emphasis here is on the culture of the institution. ${ }^{225}$ Hall goes on to mention that one characteristic of an abusive institutional culture is secrecy and apartness, a feature that can shield an organization from public scrutiny and discourage victims from complaining. ${ }^{226}$ If the abuse is kept hidden from view, even perpetrators may grow to believe in their innocence under the notion that "so long as the behaviour is not known or spoken about, it did not actually happen." 227 Particularly when offenders deal with children or other vulnerable populations who are expected to defer to authority figures of all kinds-whether police officers, guards, teachers, coaches, or doctors - there is a special risk that

\footnotetext{
219 Id. at 162.

220 Feldthusen, supra note 12 , at 228.

221 Hall, supra note 19, at 162 ("[F]raming the abuser as [an] outsider, somehow 'slipping through the cracks', fooling the gatekeepers with diabolical duplicity, is a very workable model, from the institutional perspective.").

222 Id.

223 See id. (asserting that certain institutions are more culpable because institutional conditions tend to transform normal adults into abusers).

224 Id.

225 Id

226 Id. at 162-63.

227 Id.
} 
the cultural norm of deference will facilitate abuse.228 This special risk of cultural deference to authority, coupled with a popular misconception that professionals do not abuse children, sets the stage for widespread abuse, in what Hall refers to as the "crucible" theory of vicarious liability of institutional employers. 229

For these reasons, it may be preferable to use the term "institutional liability," rather than "vicarious liability," to describe the law's decision to hold employers responsible in such settings. The term "vicarious liability" tends to showcase the individual employee's fault, implying that the employer's existence has no relevance beyond providing a financial backup for the employee. In many cases, however, something more may be going on than a simple rule requiring an employer to pay for the tortious behavior of its employee. Consistent with the "enterprise risk" rationale for imposing vicarious liability found in the torts academic literature, the term "institutional liability" better captures the causal role the employer plays in creating or facilitating the harm, even in the absence of employer negligence. In this account, responsibility is linked to the employer's causal role rather than to traditional fault, with an eye to the systemic nature of the problem that reaches beyond a few "bad apples" who infiltrate the workplace.

Although Hall applied her analysis only to sexual abuse cases occurring in residential children's homes, her cultural approach has implications for vicarious liability cases more generally. Norms of cultural deference to authority have application to cases involving teachers, police officers, physicians, and other professionals who engage in sexual misconduct, even when they abuse adult victims. Admittedly, not many institutions or enterprises are as secretive or as closed as some of the institutions Hall studied. However, they may nevertheless share some of the characteristic features of an abusive institutional culture, insofar as they fail to acknowledge that sexual misconduct is a predictable risk in their organization and thus make it more difficult for victims to report incidents and seek relief. Finally, and most significantly, Hall's critique of the "honeypot" image of sexual abuse can easily be applied to critique the restrictive "motive to serve" test in U.S. case law, which entirely misses the significance of institutional culture and rules out vicarious liability whenever the "infiltrator" is said to be motivated by sexual desire.

228 Id at $171-72$.

229 Id. at 168. 


\section{MODELS FOR LEGAL REFORM}

Although the academic developments discussed in Parts III and IV above have not had much influence on U.S. tort law, we can see their impact in other legal contexts. This section discusses two potentially important doctrinal innovations before turning to my own proposal to revise vicarious liability doctrine in sexual misconduct cases. ${ }^{230}$ It is telling that the doctrinal innovations discussed in this section surfaced only in the late 1990s, after extensive media exposure of numerous sex scandals and as courts finally came to grips with the pervasive nature of sexual abuse in the employment setting. Specifically, in the Title VII context, the U.S. Supreme Court crafted a new doctrine governing vicarious liability in sexual harassment cases that embraces the "enterprise risk" rationale for employer vicarious liability. ${ }^{231}$ At approximately the same time, in opinions that bear the traces of both mainstream and feminist scholarship, the Supreme Court of Canada, followed by the House of Lords, issued landmark rulings holding institutions vicariously liable for the sexual abuse of children in residential care.232 These precedents offer good models for legal reform of the doctrine of vicarious liability should U.S. courts ever see fit to reexamine this area of the law.

\section{A. Title VII Sexual Harassment Law}

The first model of legal reform comes from Title VII law, a particularly active area of law in which courts frequently confront issues of employer vicarious liability for the discriminatory acts of employees.233 For over a decade, lower courts had struggled with whether to impose vicarious liability in cases of sexual harassment, with many courts opting instead to require a showing of negligence before holding the employer liable under Title VII.234 Although employers had

\footnotetext{
230 See infra Parts V.A-B (discussing landmark rulings from the United States and Canada which affected the vicarious liability landscape).

231 See infra Part V.A (describing the U.S. standard of vicarious liability in Title VII cases and the rationale for the standard).

232 See infra Part V.B (articulating the Canadian approach to vicarious liability in tort law).

233 Notably, under Title VII, only the enterprise (and not individual supervisors or employees) can be held liable. Rebecca Hanner White, Vicarious and Personal Liability for Employment Discrimination, 30 GA. L. REV. 509, 509-10 (1996); see Fantini v. Salem State Coll., 557 F.3d 22, 29-30 (1st Cir. 2009) (recognizing and adopting the view that individual employees are not liable under Title VII); Miller v. Maxwell's Int'l Inc., 991 F.2d 583, 587-88 (9th Cir. 1993) (holding that employees have no personal liability under Title VII).

234 See Faragher v. City of Boca Raton, 524 U.S. 775, 799 (1998) (providing numerous examples of cases in which courts applied the negligence standard before finding employer liability).
} 
long been held vicariously liable for discriminatory firings and other "classic" discriminatory behaviors, ${ }^{235}$ many lower courts believed that cases of sexual harassment should be treated differently, echoing a version of the sexual exceptionalism we see in tort cases. These courts typically ruled that sexual harassment was "outside the scope of employment," emphasizing that sexual harassment was frequently against company policy and did not serve the interests of the employer. 236 In 1998, the U.S. Supreme Court finally resolved the issue in favor of imposing vicarious liability, subject to a special affirmative defense.237 In a highly influential pair of opinions, the Court determined that Title VII plaintiffs could recover for sexually hostile environments created by supervisors even in the absence of negligence. ${ }^{238}$ For our purposes, the most instructive opinion is Justice Souter's majority opinion in Faragher v. City of Boca Raton.239 The opinion expressly considered and critiqued the confusing body of tort law on the subject and fashioned a new doctrine utilizing both the "law and economics" and "fairness" branches of mainstream scholarship, as well as feminist insights. ${ }^{240}$ The opinion is particularly notable for its endorsement of the "enterprise risk" approach to vicarious liability, sounding the theme so prominent in the academic torts scholarship.

Justice Souter began his analysis by pointing to a number of lower courts, which had invoked the Restatement of Agency's "motive to serve" test to preclude vicarious liability for sexual harassment, ${ }^{241}$ taking the familiar position that sexual harassment was "motivated solely by individual desires and serve[d] no purpose of the employer." 242

\footnotetext{
235 Recently, however, the U.S. Supreme Court has cut back on vicarious liability for firings and other discrete discriminatory acts of lower-level supervisors when the discrimination is unknown to the actual decision-maker. See, e.g., Staub v. Proctor Hosp., $131 \mathrm{~S}$. Ct. 1186, 1194 (2011) (holding that a complaining plaintiff may hold an employer liable only if he or she first proves that the supervisor's action was "motivated by ... animus that [wa]s intended by the supervisor to cause an adverse employment action," and establishes that the supervisor's act was "a proximate cause of the ultimate employment action"); see also Charles A. Sullivan, Tortifying Employment Discrimination, 92 B.U. L. REV. 1431, 1434-50 (2012) (discussing the "cat's paw" or "subordinate bias" liability doctrine addressed by the U.S. Supreme Court in Staub).

236 See, e.g., Faragher, 524 U.S. at 784 (stating that the lower court in Faragher had classified the "harassment by [the] supervisor as a 'frolic' unrelated to his authorized tasks" and thus "outside... the scope of ... employment").

237 Id. at 807.

238 Burlington Indus., Inc. v. Ellerth, 524 U.S. 742, 746-47, 766 (1998); Faragher, 524 U.S. at $808-09$.

239 Justice Souter delivered the opinion of the Court in Faragher. Faragher, 524 U.S. at 780.

240 Id. at $795,798,803,806$.

241 Id. at 793-94.

242 Id. at 794.
} 
Although Souter noted that there was certainly a contrary line of authority holding that intentional misconduct was within the scope of employment, including Judge Friendly's famous opinion in Bushey, ${ }^{243}$ he thought it best not to attempt to reconcile the cases or to base his ruling on a "mechanical application of indefinite and malleable factors set forth in the Restatement." ${ }^{244}$ Instead, he reasoned that to impose liability under Title VII, he did not have to conclude that a supervisor was acting within the scope of employment under the traditional tests. ${ }^{245}$ Resorting to the basic rationales for imposing employer vicarious liability-discussed in Part III-Souter concluded that Title VII authorized the imposition of vicarious liability for abusive conduct committed outside the scope of authority, provided only that the offending employee was "aided" by his supervisory position in committing the offense. ${ }^{246} \mathrm{He}$ then went on to fashion a special Title VII rule that imposed vicarious liability in all cases of supervisor-created hostile environments, subject to an affirmative defense. ${ }^{247}$

Souter started from the proposition that it is "now well recognized that hostile environment sexual harassment by supervisors... is a persistent problem in the workplace." ${ }^{248}$ Tracking the fairness case for vicarious liability, ${ }^{249}$ he explained that because sexual harassment is such a constant risk, he considered it fair to hold employers vicariously liable as "one of the costs of doing business, [a cost] to be charged to the enterprise rather than the victim." 250 Like the economic scholars, Justice Souter also pointed out the efficiency-enhancing qualities of vicarious liability, noting that "the employer has a greater opportunity to guard against misconduct by supervisors... [and a] greater opportunity and incentive to screen them, train them, and monitor their performance."251 Finally, he drew upon feminist scholarship and stressed the importance of job-created power in facilitating harassment and defusing potential resistance by victims. ${ }^{252}$ Citing an article by feminist scholar Susan

243 Id. at 794, 796; see supra text accompanying notes 85-90 (providing an in-depth discussion of Judge Friendly's opinion in Bushey).

244 Faragher, 524 U.S. at 796-97.

245 See id. at 797 (framing proper analysis as requiring an inquiry "into the reasons that would support a conclusion that harassing behavior ought to be held within the scope of a supervisor's employment, and the reasons for the opposite view").

246 Id. at 802

247 Id. at 807

$248 \quad$ Id. at 798.

249 See supra Part III.B (discussing the faimess rationale for vicarious liability).

$250 \quad$ Faragher, 524 U.S. at 798.

251 Compare Keating, supra note 142, at 1270 (discussing the efficiency rationale behind vicarious liability), with Faragher, 524 U.S. at 803.

252 Faragher, 524 U.S. at 803. 
Estrich, Souter stated that a supervisor's actions "necessarily draw upon his superior position over the people who report to him, or those under them, whereas an employee generally cannot check a supervisor's abusive conduct the same way that she might deal with abuse from a coworker." 253

Justice Souter's endorsement of vicarious liability in the Title VII context is fundamentally grounded on an "enterprise risk" approach to vicarious liability. The "good reasons" he cites for imposing vicarious liability 254 -fairness, efficiency, and job-created power-all look to the causal connections between employment and the abusive behavior, rather than whether the offending employee was motivated to serve the employer's interests. 255 The holding in Faragher is thus a good example of institutional liability predicated on causation, rather than negligence. Particularly because Title VII's statutory scheme is a form of enterprise liability that does not even authorize claims against individual employees, ${ }^{256}$ it makes good sense to adopt such an approach in Title VII cases. However, Justice Souter's reasoning in Faragher is not specific to statutory civil rights cases and could well be adopted for tort cases involving employee sexual misconduct. The principal take-away message is that when faced with a choice between negligence and vicarious liability, the Court elected not to carve out a sex exception to vicarious liability.

This endorsement of vicarious liability in the sexual harassment context is notable, particularly when considering that the bar for proving a sexually hostile environment under Title VII is lower than that imposed upon tort plaintiffs when they assert similar claims for intentional infliction of emotional distress. ${ }^{257}$ In this respect, many of the tort cases refusing to hold employers vicariously liable for employee sexual abuse cases-involving physical abuse of children or vulnerable adults-are more egregious than the typical Title VII hostile environment claim. It is also significant that the Supreme Court chose a bright line rule in favor of vicarious liability, rather than a case-by-case determination of whether a particular employee has abused his special

\footnotetext{
253 Id. (citing Susan Estrich, Sex at Work, 43 STAN. L. REV. 813, 854 (1991)).

254 Id. at 804.

255 See id. at 798, 803 (discussing the fairness, efficiency, and job-created power rationales for imposing vicarious liability).

256 See Miller v. Maxwell's Int'1 Inc., 991 F.2d 583, 588 (9th Cir. 1993) (holding that Title VII does not impose liability on employees in their individual capacities).

257 See Martha Chamallas, Discrimination and Outrage: The Migration from Civil Rights to Tort Law, 48 WM. \& MARY L. REV. 2115, 2127-32 (2007) (discussing the higher threshold for intentional infliction of emotional distress claims).
} 
supervisory authority. ${ }^{258}$ The Court apparently did not want to replicate the experience of common law courts and produce another confusing and indeterminate body of cases.

In two important respects, however, the U.S. Supreme Court refrained from imposing automatic liability on employers for sexual harassment committed by employees. First, it limited vicarious liability solely to hostile environments created by supervisory employees. ${ }^{259} \mathrm{By}$ contrast, to prevail in a hostile environment case created by coemployees, the plaintiff must prove that the employer was negligent. ${ }^{260}$ This limitation is partly explained by the specific statutory language of Title VII that defines "employer" to include "any agent" of the employer, ${ }^{261}$ a provision the Court has relied on to distinguish supervisory employees from co-workers and to justify its decision to limit vicarious liability to acts supervisors commit. ${ }^{262}$ Reserving vicarious liability only for supervisor-created hostile environments is a significant restriction on employer liability, especially given the Court's recent ruling adopting an extremely narrow definition of "supervisor." 263 However, it is important to realize that Title VII's restriction of vicarious liability to supervisory employees would not necessarily carry over to tort law if courts decided to borrow Justice Souter's approach in Faragher as a model of reform. Particularly in cases in which the offending employee, though technically not a supervisor, exercises job-created authority or power over the non-employee plaintiff, the "enterprise risk" rationale for imposing vicarious liability on the employer may still stand, regardless of the classification of the offending employee.

Second, and more important for our purposes, in the Title VII sexual harassment context, the U.S. Supreme Court was not content to impose automatic vicarious liability based solely at the actions of the offending employee, ${ }^{264}$ but instead created an escape hatch for employers based in part on the actions of the victim plaintiff. The Court fashioned a special

$258 \quad$ Faragher, 524 U.S. at 802.
259 Id. at 807.

260 See Vance v. Ball State Univ., 133 S. Ct. 2434, 2453 (2013) ("Assuming that a harasser is not a supervisor, a plaintiff could still prevail by showing that his or her employer was negligent in failing to prevent harassment from taking place.").

${ }_{261}$ Civil Rights Act of 1964, 42 U.S.C. $\$ 2000 \mathrm{e}(\mathrm{b})(2006)$.

262 See Faragher, 524 U.S. at 791-92, 802 (relying, in part, on Title VII's definition of "employer" in determining that an employer may be held liable for a supervisor's tortious conduct "made possible by abuse of his supervisory authority").

263 Vance, 133 S. Ct. at 2443 (defining "supervisor" as an employee empowered "to take tangible employment actions against [a] victim," such as a firing, demotion, or pay cut).

264 See Faragher, 524 U.S. at 804 (recognizing that the Court's theory of vicarious liability must comport with the Court's prior ruling in Meritor Savings Bank $v$. Vinson that an employer is not automatically liable for its supervisor's harassment). 
affirmative defense by which an employer could escape liability if it proved both that it had acted reasonably in taking steps to prevent and correct harassment and that the plaintiff had acted unreasonably in failing to use the employer's internal grievance procedure to report the harassment and mitigate his or her harm. ${ }^{265}$ This strange animalvicarious liability with a negligence-sounding affirmative defense-was tailor-made by the Court to effectuate Title VII policies, providing an incentive for employers to create adequate grievance procedures and for employees to limit damages by promptly reporting the conduct and giving their employer an opportunity to nip the harassment in the bud before it escalated.266 Tellingly, the defense was designed to fit cases involving a continuing course of conduct, such as hostile environment sexual harassment cases, which tend to escalate over time. And, most importantly, it also presupposes a situation in which the employer controls and regularly interacts with both the victim and the perpetrator of the offense.

Interestingly, the Title VII affirmative defense to vicarious liability does not function like the typical comparative negligence defense to negligence liability. Rather, the defense is two pronged - the employer may establish the affirmative defense only by proving that its overall system for dealing with and preventing harassment is sound and that the plaintiff could have prevented or mitigated her harm by filing an internal complaint. 267 While this escape hatch has proven very valuable to employers as a practical matter, ${ }^{268}$ it is important to recognize that the affirmative defense does not convert Title VII into a negligence regime. Rather, the affirmative defense is essentially a "no causation" defense to vicarious liability, requiring the employer to show that the employee caused or aggravated her own injury by not using the employer's wellfunctioning system. As such, it fits within an enterprise risk theory of vicarious liability and is not dependent on any showing that the offending employee was somehow furthering the employer's business. This affirmative defense thus is the kind of victim defense envisioned by economic scholars who have endorsed vicarious liability and have

\footnotetext{
265 Id. at 807.

266 Id. at $805-06$.

$267 \quad$ Id. at 807.

268 See John H. Marks, Smoke, Mirrors, and the Disappearance of "Vicarious" Liability: The Emergence of a Dubious Summary-Judgment Safe Harbor for Employers Whose Superoisory Personnel Commit Hostile Environment Workplace Harassment, 38 Hous. L. REV. 1401, 1422-23 (2002) (explaining that since Faragher, lower courts have routinely granted summary judgment in favor of employers in harassment claims).
} 
sought a way to calibrate the incentives among the various actors to achieve optimal deterrence and efficiency. ${ }^{269}$

Finally, Title VII's affirmative defense is not a defense that can easily be carried over to the tort context where plaintiffs typically have no contractual or even ongoing relationship to the enterprise and where the harm suffered is often not a result of a continuing offense but a one-time assault. In the typical tort case involving plaintiffs who are children, patients, students, or customers, it makes little sense to insist that they complain to the employer after the fact in order to prevent future abuse. Unlike the Title VII context, plaintiffs in tort cases most often have no interest in protecting their jobs or changing the working environment. Therefore, the special circumstances present in cases of workplace sexual harassment that arguably support a victim-based affirmative defense do not generally pertain to tort cases involving sexual abuse of nonemployee plaintiffs.

\section{B. The Canadian Approach}

Although Justice Souter's opinion in Faragher is an important endorsement of vicarious liability in sexual misconduct cases, it is admittedly a qualified precedent for reform, limited to Title VII cases and considerably restricted in scope. A much better example of how the enterprise risk model of vicarious liability can be applied in the torts context comes from a pair of cases decided in 1999 by the Supreme Court of Canada. 270 Outside the United States, these cases have already been recognized as landmark cases.271 The House of Lords has gone so far as to declare that " $[w]$ herever such problems are considered in [the] future in the common law world these judgments will be the starting point."272

In Bazley v. Curry, the Supreme Court of Canada imposed vicarious liability on the Children's Foundation, a non-profit organization which operated facilities for the treatment of emotionally disturbed children between the ages of six and twelve. ${ }^{273}$ The foundation hired a person the

\footnotetext{
269 See, e.g., Sykes, supra note 19, at 570 (discussing workplace incentives as a means of avoiding employee misconduct); supra Part III.A (discussing the law and economics perspective).

270 Bazley v. Curry, [1999] 2 S.C.R. 534 (Can. B.C.); Jacobi v. Griffiths, [1999] 2 S.C.R. 570 (Can.).

27 See, e.8., Bruce Feldthusen, Civil Liability for Sexual Assault in Aboriginal Residential Schools: The Baker Did It, 22 CANADIAN J.L. \& SOC'Y 61, 82-83 (2007) (discussing the "significant and groundbreaking decision in Bazley $v$. Curry").

272 Lister v. Hesley Hall Ltd., [2001] UKHL 22, [2002] 1 A.C. 215 (H.L.) [27] (appeal taken from Eng.).

$273 \quad 2$ S.C.R. at para. $2,58$.
} 
court described as a "pedophile" to work in one of the homes. 274 Before he was hired, the employee was checked out and, as far as the employer knew, was a suitable employee. ${ }^{275}$ As the court described the facts, over a course of months the employee began a "seduction" of a young, emotionally vulnerable child, whereby "step by subtle step, bathing became sexual exploration; tucking in in a darkened room became sexual abuse." 276 When the abuse came to light, the foundation immediately discharged the employee who was subsequently prosecuted and convicted of criminal sex abuse. ${ }^{277}$

The court recognized that vicarious liability could be imposed on the basis of the then-prevailing rule in Canada-similar to the "motive to serve" test - that required a showing that the offending employee was performing an authorized act in an unauthorized manner or mode. ${ }^{278}$ Indeed, the trial court had ruled for the plaintiff on this basis, relying on the fact that the offending employee had the authority to put the child to bed, although he acted in an unauthorized manner in molesting the child.279 The court also considered precedents holding banks and other custodians of property vicariously liable for thefts committed by dishonest employees. ${ }^{280}$ Advocates for abused children had argued that the theft cases should be applied by analogy to child sex abuse cases to avoid the anomaly of "'attributing a higher standard to the way society looks after its jewellery than its children." 281 However, the court chose not to base its decision on the old formulas or precedents and instead undertook a thorough re-examination of the policies and rationales underlying vicarious liability. ${ }^{282}$ Its re-examination led the court to embrace the enterprise risk approach to vicarious liability. ${ }^{283}$

Citing the scholarship of Alan Sykes ${ }^{284}$ and the notable comparative torts scholar John Fleming, ${ }^{285}$ the court declared that the critical question was whether the employer's enterprise created or materially enhanced the risk of the tortious act. ${ }^{286}$ In its view, the enterprise risk approach best effectuated the twin policy goals of providing effective and fair

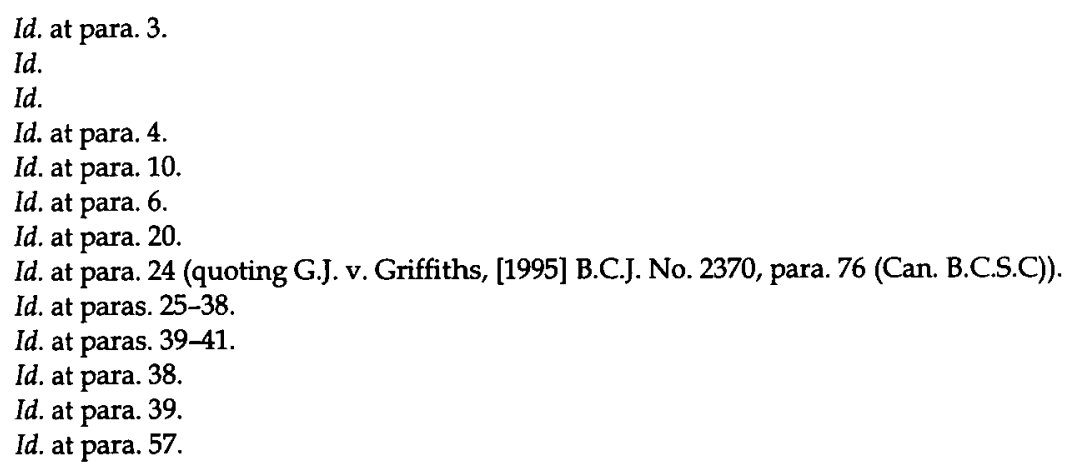


compensation and deterring future harm. ${ }^{287}$ The court's opinion largely embraced the "fairness" case for vicarious liability discussed earlier, ${ }^{288}$ with economic arguments playing an important but secondary role. Reviewing the history of the vicarious liability doctrine, the court stated that " $[t]$ he common theme resides in the idea that where the employee's conduct is closely tied to a risk that the employer's enterprise has placed in the community, the employer may justly be held vicariously liable for the employee's wrong." 289 It is this "close" or "significant" causal connection that triggers vicarious liability, even if the employee's conduct is unrelated to the employer's desires. ${ }^{290}$

The Canadian court was careful to distinguish its "enterprise causation" approach - or what it termed a focus on "general cause"291 from the foreseeability test used to determine negligence. It stressed that the emphasis is not on the foreseeability of specific risks (e.g., whether one could foresee that a particular person might molest a child), but on the "foreseeability of the broad risks incident to a whole enterprise." 292 In this respect, the court echoed Judge Friendly's distinction in Bushey between foreseeability and risks that were "characteristic of [the] activities" of the enterprise. 293

The innovative aspect of Bazley is its application of "enterprise risk" to the realm of intentional torts and sexual abuse in particular. Despite the long history of the "enterprise risk" approach, Bazley is the first major decision to show how the approach relates to the systemic problem of sexual abuse. To this end, the Supreme Court of Canada enunciated a list of five subsidiary factors to guide the determination of whether the connection between an enterprise and the sexual misconduct is sufficient to warrant imposition of vicarious liability. ${ }^{294}$ In my view, this list is the lasting contribution of the case.

The first factor Bazley provides is opportunity-namely, "the opportunity that the enterprise afforded the employee to abuse his or her power." 295 The court was careful not to equate "opportunity" with mere presence of "but-for" causation, a test that is satisfied even when there is

Id. at para. 46 .

288 Id. at para. 30; see supra Part III.B (discussing the fairness rationale for vicarious liability).

289 Bazley, 2 S.C.R. at para. 22.

290 Id. at para. 41.

291 Id. at para. 40.

292 Id. at para. 39 (citing J.G. FLEMING, THE LAW OF TORTS 422 (9th ed. 1998)).

293 Ira S. Bushey \& Sons, Inc. v. United States, 398 F.2d 167, 171 (2d Cir. 1968).

294 Bazley, 2S.C.R. at para. 41.

295 Id. 
only a coincidental link between the tort and the employment. ${ }^{296}$ Rather, the court envisioned situations in which the employment provided a "significant" opportunity to abuse, such as "a peculiarly custody-based tort like embezzlement or child abuse [where] the opportunity provided by the employment situation becomes much more salient." ${ }^{297}$ The second subsidiary factor the court listed was "the extent to which the wrongful act ... furthered the employer's aims." 298 Notice here that the old test for vicarious liability becomes merely one of several factors to consider. ${ }^{299}$ In the court's view, motive to serve is relevant only in the probabilistic sense that it increases the likelihood that a wrongful act will be committed by an employee who has a built-in incentive to further his or her employer's mission. ${ }^{300}$ The third factor relates to the nature of the job, namely, whether "the wrongful act was related to friction, confrontation[,] or intimacy inherent in the employer's enterprise." 301 The court expressed the view that "[t]o require or permit an employee to touch the client in intimate body zones may enhance the risk of sexual touching, just as permitting an employee to handle large sums of money may enhance the risk of embezzlement or conversion." 302 The fourth factor is concerned with power, specifically, "the extent of power conferred on the employee in relation to the victim." ${ }^{303}$ The court acknowledged the importance of job-related power in establishing a nexus between employment and abuse and stated that "the more an enterprise requires the exercise of power or authority for its successful operation, the more materially likely it is that an abuse of that power relationship can be fairly ascribed to the employer." ${ }^{304}$ The fifth and final factor is vulnerability, namely, "the vulnerability of potential victims to [the] wrongful exercise of the employee's power." 305 The court was particularly sensitive to the plight of children whose abusers stand in a "role-model relationship" with the child and whose vulnerability is increased in situations where the institutional culture "encourages the employee to stand in a position of respect and suggests that the child should emulate and obey the employee." ${ }^{306}$ In concluding, the court

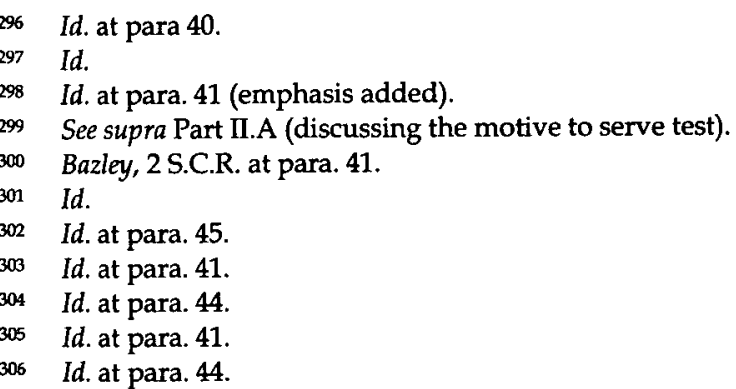


mentioned that "[t]ime and place arguments may also be relevant in particular cases." 307

Notably, the five factors listed above do not constitute a specific test for vicarious liability, but are simply considerations for courts to use in applying the general standard for intentional tort cases (i.e., whether the enterprise created or materially enhanced the risk of abuse). ${ }^{308}$ In marked contrast to the bright line test articulated by the U.S. Supreme Court in Faragher, the Supreme Court of Canada anticipated that courts and juries would apply the broad standard announced on a case-by-case basis, without stating in advance how each of the guiding factors should be weighed.

In Bazley, the court had little difficulty concluding that application of the factors to the facts of the case pointed in the direction of liability - the opportunity for abuse was present in a situation in which the employee was expected to be alone with a child for extended periods of time in a relationship of power and intimacy. ${ }^{309}$ Particularly in the case of a young, vulnerable child who was expected to respect and defer to the offending employee, the risk of abuse was enhanced. ${ }^{310}$ The court, therefore, was confident that the abuse that occurred at the Children's Foundation "was not a mere accident of time and place, but the product of the special relationship of intimacy and respect the employer fostered, as well as the special opportunities for exploitation of that relationship it furnished."311 The court, however, recognized that future cases might not "rise to the same level to impose vicarious liability." 312

The influence of the Bazley decision was soon felt in the common law world. Relying on the Canadian decision, the House of Lords reached the same conclusion in a case decided two years later involving the molestation of residents by the warden of a boarding school for emotionally disturbed children. ${ }^{313}$ The highest court went on record as stating that "[c]ases which concern sexual harassment or sexual abuse committed by an employee should be approached in the same way as any other case where questions of vicarious liability arise[]." 314

\footnotetext{
307 Id. at para. 45.

308 See id. at para. 41 (explaining that the factors considered may vary depending on the nature of the case).

309 Id. at para. 58 ("[I]t is difficult to imagine a job with a greater risk for child sexual abuse.").

310 Id. at paras. 44,58 .

$311 \quad$ Id. at para. 58.

312 Id.

${ }^{313}$ Lister v. Hesley Hall Ltd., [2001] UKHL 22, [2002] 1 A.C. (H.L.) [2, 28-29] (appeal taken from Eng.).

314 Id. at [48].
} 
It cannot be denied, however, that cases involving molestation of young children in residential care are perhaps the easiest for courts to impose vicarious liability. Even in the United States, some courts have seen fit to impose vicarious liability in this factual context. ${ }^{315}$ Thus, the existence of the multi-factor approach, without more, does not guarantee greater acceptance of vicarious liability. Instead, like its predecessors, the multi-factor approach is indeterminate, dependent on the facts of the case and how broadly or narrowly individual judges interpret the scope of the risks of a particular enterprise. Even slight differences in the facts can produce different results. Thus, the same day the Supreme Court of Canada decided Bazley, a divided court (4-3) reached a different result in a case against a boys' and girls' club that had organized recreational activities and occasional outings. ${ }^{316}$ An employee, who had been held up as a role model, sexually molested two children in the program, off hours and off site. ${ }^{317}$ Over a strong dissent, the court found no vicarious liability because of the absence of a parent-type relationship, intimacy, or special relationship of trust. ${ }^{318}$

Although by no means a panacea, the Canadian multi-factor approach based on enterprise risk represents a considerable improvement over the two approaches used by U.S. courts. Unlike the "motive to serve" test, the Bazley standard, with its guiding factors, was fashioned with intentional tort and sexual abuse cases in mind and thus avoids the kind of tortured application of the "motive to serve" test found in some U.S. cases imposing vicarious liability. Although it resembles the more liberal tests centered on foreseeability and risk creation, the five guiding factors articulated in Bazley represent an advance in thinking about sexual abuse cases. ${ }^{319}$ The five factors are expressly designed to encourage courts to fully articulate the reasons for their decision and to go beyond merely labeling a plaintiff's injury as "foreseeable" or "a predictable risk." In this respect, Bazley resembles the new Restatement of Torts (Third), which has shown distaste for vague "foreseeability" standards. ${ }^{320}$ In determining duty in negligence cases,

315 See, e.g., Stropes v. Heritage House Childrens Ctr. of Shelbyville, Inc., 547 N.E.2d 244, 245, 254 (Ind. 1989) (applying the non-delegable duty doctrine to hold that liability may be imposed on a group home for molestation of disabled minor resident); Fahrendorff ex rel Fahrendorff v. N. Homes, Inc., 597 N.W.2d 905, 912 (Minn. 1999) (imposing liability on group home operator for a sexual assault by its program officer).

316 Jacobi v. Griffiths, [1999] 2S.C.R. 570, paras. 3-4, 66 (Can.).

317 Id. at paras. 4,36 .

318 Id. at paras. 2, 29.

319 See supra text accompanying notes 295-307 (discussing the five-factor test articulated in Bazley).

320 Compare RESTATEMENT (THIRD) OF TORTS: LIABILITY FOR PHYSICAL AND EMOTIONAL HARM $\$ \$ 7 \mathrm{cmt}$. j, $37 \mathrm{cmt}$. $f(2010)$ (rejecting the foreseeability standard as a basis for no- 
the new Restatement rejects a foreseeability approach in favor of a default imposition of duty, unless the court articulates a "countervailing principle or policy" for denying or limiting liability. ${ }^{321}$ Most significantly in my view, the Canadian approach also allows room for the insights from feminist theory, cognitive psychology, and the scholarship on institutional culture-discussed in Part IV - to be poured into its multifactor analysis and affect legal decision-making.

First, the Canadian multi-factor approach responds to the feminist critique of this area of law by directing the fact-finders' attention to the factors of opportunity, power, and vulnerability. ${ }^{322}$ By doing so, it counters the sexual exceptionalism and undue emphasis on the perpetrators' sexual desires that characterizes much of the current U.S. case law. These three factors remind us that people abuse not only to satisfy their lust, but because they are able to do so (often without detection). The factors highlight the advantaged positions of offenders vis-à-vis their victims, taking note of their job-created power over vulnerable persons who are not in a good position to resist the abusive conduct.

Second, the multi-factor approach also responds to the insights of cognitive psychology by helping to avert cognitive bias. It counters the fundamental attribution error, which mistakenly locates the cause of an event solely in the disposition or psychology of the actor, missing the significance of situational factors. ${ }^{323}$ By highlighting the factors of opportunity, (job-created) power, and the nature of the job-particularly a job that carries with it intimate contact with the victim - the fact-finder is forced to give consideration to situational factors. This focus also permits judges and juries to consider whether sexual abuse is a product of multiple causes, countering the bias toward monocausality and the tendency to think in dichotomous (either/or) terms. ${ }^{324}$

Finally, taken together, the factors also point in the direction of identifying an abusive institutional culture which fosters or enables sexual misconduct of employees who might not otherwise have seized

duty rulings), with Bazley v. Curry, [1999] 2 S.C.R. 534, para. 39 (Can.) (rejecting the foreseeability standard in favor of a standard based on fairness).

321 RESTATEMENT (THIRD) OF TORTS: LIABILITY FOR PHYSICAL AND EMOTIONAL HARM $§ 7$ \& cmt. j (2010); W. Jonathan Cardi \& Michael D. Green, Duty Wars, 81 S. CAL. L. REV. 671, 682, 729 (2008). Of course, foreseeability is still a major factor in determining whether a defendant breached its duty in negligence cases. RESTATEMENT (THIRD) OF TORTS: LIABILITY FOR PHYSICAL AND EMOTIONAL HARM $\$ 3$ (2010).

322 Bazley, 2 S.C.R. at para 41.

323 See supra text accompanying notes 202-07 (discussing the fundamental attribution theory and how it impacts decision-making).

324 See supra text accompanying note 212-15 (discussing bias toward monocausality and how it eclipses mixed motivation cases). 
the opportunity, taken the risk, or even had the desire to engage in the misconduct. Although there is no specific mention of "institutional culture" in the five factors listed in Bazley, the overall approach centers on institutional features and in this way encourages a shift in the way we conceptualize this type of harm. The Bazley standard thus has the potential to move the discourse away from an attempt to ferret out those bad individuals who infiltrate an organization to a focus on conditions that facilitate abuse.

\section{A Proposed Rule for U.S. Courts}

Despite its considerable virtues, it is doubtful that the Canadian multi-factor approach will find favor in U.S. courts. The Canadian courts have been more comfortable with having policy considerations drive results, compared to U.S. courts, which more often feel the need to couch their opinions solely in the rhetoric of legal principle. In U.S. tort law, moreover, there is a trend away from multi-factor approaches guided by general standards, in favor of more highly specified rules. Put simply, standards are "out," rules are "in." The trend is most obvious in the Restatement of Torts (Third), for example, in its new formulations for strict liability for abnormally dangerous activities, ${ }^{325}$ and its new rule for bystander liability in emotional distress cases. ${ }^{326}$ In each of these instances, the Restatement has crafted a black letter rule that specifies the requisites for liability, rather than letting courts and juries, in a case-bycase manner, consider a number of factors with no pre-set weights. Moreover, it is notable that the U.S. Supreme Court in the Title VII context likewise opted for a specified rule of automatic vicarious liability with an affirmative defense, ${ }^{327}$ as opposed to a case-by-case determination of whether a given supervisory employee abused his authority based on a number of factors. ${ }^{328}$

This preference for specified rules over standards likely stems from a desire to provide trial courts with a crisp rule to aid them in deciding whether to send a case to the jury and to provide more precise guidance to juries in their deliberations. ${ }^{329}$ I doubt, however, that rules as opposed

\footnotetext{
325 RESTATEMENT (THIRD) OF TORTS: LIABILITY FOR PHYSICAL AND EMOTIONAL HARM $\$ 20$ \& cmt. $\mathrm{k}(2010)$.

326 RESTATEMENT (THIRD) OF TORTS: LIABILITY FOR PHYSICAL AND EMOTIONAL HARM $§ 48$ (2012).

327 Faragher v. City of Boca Raton, 524 U.S. 775, 807 (1998).

$328 \quad$ Id. at 805.

329 See Restatement (THIRD) OF TORTS: Liability For Physical and EMOTIONAL HaRm $\S 48$ note (2012) (" $[\mathrm{A}]$ number of courts ... have decided that the open-ended foreseeability approach to bystander liability was unworkable and have instead employed a rule-based approach to bystander claims.").
} 
to standards are inherently more likely to accomplish this objective. It is unclear whether specified rules always provide the guidance they promise. After all, the "motive to serve" test is itself a specified rule that has proven to be notoriously indeterminate and incapable of providing the kind of guidance that leads to predictable results. ${ }^{330}$ Admittedly, the Canadian multi-factor approach also runs the risk of being applied very differently by varying decision makers. For example, those courts which place more emphasis on the factor of opportunity and do not demand that each of the other factors point unambiguously in the direction of liability will be much more likely to impose vicarious liability than courts that wish to limit vicarious liability to situations involving children, vulnerable people in custodial care, or assaults that take place during business hours on company property. Given the indeterminacy of both specified rules and multi-factor approaches, the choice of one technique over the other may not be outcome-determinative but may merely constitute a preference for how governing doctrines are articulated or formulated.

If I am correct about the current preference of U.S. courts, it might be helpful to fashion a rule that takes into account the content of Bazley's five factors-and one that is designed with recurring cases of sexual abuse in mind-but yet is not formulated as a broad standard with a number of guiding factors. Thus, if U.S. courts prefer to adopt a specified rule to govern the imposition of vicarious liability in sexual abuse cases, I would propose the following: Vicarious liability shall be imposed if an employer materially increases the risk of tortious action either by conferring power or authority on its employees over vulnerable persons or by regularly placing its employees in situations of intimate or personal contact with clients, customers, or other potential victims.

Such a rule has the advantage of being explicitly based on "risk creation" and "risk causation." The rule triggers vicarious liability in cases in which the employer "materially increases the risk of tortious action" 331 and thus rejects the "motive to serve" test that is so ill-suited to determine liability for sexual abuse. The rule incorporates Bazley's key factors of "power" and "vulnerability" through the first qualifying phrase that requires proof of an employer's "conferring power or authority on its employees over vulnerable persons." ${ }^{332}$ It thus highlights the imbalance or asymmetry in the social positions of

330 See supra Part II.A (discussing the motive to serve test and the varying results it has produced).

331 See this Article's proposal of a new rule for vicarious liability in the preceding paragraph.

${ }_{332}$ Cf. Bazley v. Curry, [1999] 2 S.C.R. 534, para 41 (Can.) (articulating a multi-factor test including the factors of power and vulnerability). 
offenders and victims that characterizes modern sexual abuse cases. The second qualifying phrase - "regularly placing its employees in situations of intimate or personal contact with clients, customers, or other potential victims" - incorporates the factors of "opportunity" and "nature of the job." ${ }^{333}$ It zeros in on the special access to victims some types of employment provide when certain jobs require employees to touch, counsel, or otherwise interact with people in ways that would be considered "personal" or "intimate" were it not for the nature of the job. The rule is thus very much influenced by Bazley's multi-factor approach but, in line with the preference for specified rules, condenses and coverts Bazley's five factors into two alternative qualifications or requisites.

Most notably, such a rule would result in vicarious liability in the vast majority of cases discussed in this Article. The rule would cover sexual abuse by caretakers of young children in residential homes; 334 abuse by medical personnel during exams; 335 abuse by guards conducting searches; $; 36$ and abuse by teachers, ${ }^{337}$ clergy, ${ }^{338}$ Boy Scout leaders, ${ }^{339}$ police officers, 340 or other authority figures who molest their charges. It is thus frankly designed to overturn the restrictive line of cases that treats sexual abuse as qualitatively different from other types of employee misconduct and that has generally resulted in no vicarious liability except for unusual cases where the sexual abuse can be characterized as somehow furthering the employer's mission under the particular circumstances.341 Adoption of such a proposed rule would mark a major shift in U.S. case law, reversing the current ambivalence toward "risk creation" models and setting U.S. courts on a course that resembles the Canadian approach.

333 See supra text accompanying notes 295-97, 301-02 (discussing factors of opportunity and nature of the job set out in Bazley).

334 See supra text accompanying note 66 (discussing the holding in Fahrendorff ex rel. Fahrendorff v. N. Homes, Inc., 597 N.W.2d 905, 907 (Minn. 1999)).

335 See supra text accompanying notes 67-72 (discussing Lisa M. v. Henry Mayo Newhall Mem'l Hosp., 907 P.2d 358, 359 (Cal. 1995)); supra text accompanying notes 61-64 (discussing Buck v. Blum, 130 S.W. 3d 285, 287-88 (Tex. App. 2004)).

336 See supra text accompanying notes 57-59 (discussing Brown v. Argenbright Sec., Inc., 782 A.2d 752, 755-56 (D.C. 2001)).

337 See supra text accompanying notes 73-77 (discussing John R. v. Oakland Unified Sch. Dist., 769 P.2d 948, 949 (Cal. 1989)).

338 See supra text accompanying notes 192-93 (discussing Gibson v. Brewer, 952 S.W.2d 239, 243 (Mo. 1997)); supra text accompanying note 65 (discussing Fearing v. Bucher, 977 P.2d 1163, 1164 (Or. 1999)).

339 See supra note 56 (discussing Lourim v. Swensen, 977 P.2d 1157, 1159 (Or. 1999)).

340 See supra text accompanying note 79 (discussing Mary M. v. City of Los Angeles, 814 P.2d 1341, 1342-43 (Cal. 1991)).

341 See supra Part II.C (analyzing cases that have treated sexual abuse differently from other types of intentional torts). 
However, it should be noted that the proposed rule does not cover every case in which an employee engages in sexual abuse on the job. Similar to the Canadian approach, the proposed rule requires more than a mere "but-for" connection between the abuse and the employment. For example, the proposed rule would not cover a hypothetical case in which an adult law student is raped by a custodian who works in the law school building. Although proximity in the law school would certainly provide the custodian access to the student, the case is arguably different from those discussed in this Article. In the hypothetical case, the custodian has no job-conferred power or authority over the student, nor does the custodian's job afford him the right to touch the student or otherwise give him rightful access to her person. Under the proposed rule, there would be no vicarious liability because neither of the two alternative requisites is satisfied. As under current law, to impose liability on the employer in such a case, the plaintiff would have to prove that the employer was independently negligent.

Some might object to the proposed rule precisely because it would not cover cases such as the hypothetical case. The argument would be that if we are going to change the law with respect to vicarious liability, we should not be content with half-way measures and should instead adopt a broader rule that imposes vicarious liability whenever employees commit sexual abuse on the job. Indeed, one scholar has argued that we should give up on what he regards as the fruitless exercise of requiring plaintiffs to prove precisely how the employment enhanced the risk of abuse, or bore a "close connection" to their harm, and simply require a showing of a "but-for" causal connection between the abuse and the employment. ${ }^{342}$ Such a "but-for" standard would presumably allow imposition of vicarious liability whenever the employment provided an opportunity for an offender to encounter the victim, saving courts and juries the difficult task of evaluating whether that opportunity was "sufficient" enough or "material" enough to impose liability.

As attractive as such a "but-for" rule may at first blush appear, in the end, I do not believe that courts would dispense with evaluating the quality of the causal connection in particular cases. In other contexts, courts have been loath to impose liability when the causal connection between the defendant's conduct and the harm is viewed as merely coincidental. Whether characterized as an aspect of factual causation or one of proximate cause, courts have consistently refused to impose liability when, in the language of the Restatement of Torts (Third), "the

Feldthusen, supra note 12, at 224. 
tortious aspect of the actor's conduct [is] of a type that does not generally increase the risk of that harm." ${ }^{343}$ Thus, in the classic example where a speeding car happens to be hit by a tree crashing onto the car without warning, the driver will not be liable to his injured passenger, even though had the driver refrained from speeding the car would not have arrived at the precise location of the tree at the time it fell. ${ }^{344}$ Because speeding is not the type of conduct that generally increases the risk of crashing trees, the causal link is thought to be "serendipitous or coincidental" and regarded as insufficient to support liability. ${ }^{345}$

In the vicarious liability context, regardless of the precise test used, there would likely be considerable pressure for courts to apply a similar exemption in cases of mere "coincidence." For example, even liberal courts often go to pains to rule out the possibility of liability in situations in which the employment seems to have only a "coincidental" relationship to the abuse.346 Judge Friendly, for example, opined that there would be no vicarious liability if the seaman in Bushey had "recognized the Bushey security guard as his wife's lover and shot him." "347 In such a case, where the security guard's job was linked to the time and location of the confrontation, but in no other way seemed to facilitate the violence, the incident cannot be said to be "characteristic of the activities" of the enterprise. Imposing vicarious liability in such a case would thus undercut one of the principal rationales for the imposition of vicarious liability, even if but-for causation were present. 348 The realistic choice then is not between a simple but-for causation standard and a standard that turns on a showing that the employment

343 RESTATEMENT (THIRD) OF TORTS: LIABILITY FOR PHYSICAL AND EMOTIONAL HARM $\$ 30$ (2010); see, e.g., Royal Indem. Co. v. Factory Mut. Ins. Co., 786 N.W.2d 839, 850-52 (lowa 2010) (relying on section 30 to deny liability and reasoning that the plaintiff failed to establish that a company's deficient inspection increased the risk of the type of harm suffered).

344 RESTATEMENT (THIRD) OF TORTS: LIABILITY FOR PHYSICAL AND EMOTIONAL HARM $\$ 30$ illus. 1 (2010).

345 Id. $\$ 30 \mathrm{cmt}$. a.

346 See, e.g., Lisa M. v. Henry Mayo Newhall Mem'1 Hosp., 907 P.2d 358, 364-65, 367 (Cal. 1995) (holding that, although the employee's job involved intimate contact with patients, the employer was not liable because the resulting sexual assault was not a foreseeable consequence of the physical contact).

347 Ira S. Bushey \& Sons, Inc. v. United States, 398 F.2d 167, 172 (2d Cir. 1968); see JoHN G. FLEMING, THE LAW OF TORTS 427 (9th ed. 1998) ("Clearly, vicarious liability should not stretch to an employee beating up his wife's lover though it be on the working site and during working hours ....").

348 In some cases, it will be debatable whether even "but-for" causation is present, given that the defendant in a "wife's lover" scenario will argue that the offender would probably have tracked down the victim and attacked him in another location if he had not encountered the victim at the worksite. 
"materially increased" the risk of abuse or some similar enhanced causation showing. Rather, I believe that courts will likely continue to insist on something more than mere but-for causation, and the challenge becomes how best to express that additional causal requirement. The proposed rule uses the language of "materially increas[ing]" the risk-a phrase that has gained currency in the academic literature and the courts - rather than drafting a rule which imposes vicarious liability except where the causal connection is merely "coincidental" or "fortuitous." Interestingly, similar to the proposed rule, a "coincidental" exception to vicarious liability would likely also rule out vicarious liability in the hypothetical rape case discussed above, unless the victim could specify how the custodian's job facilitated the abuse beyond providing a time and place for the assault. Thus, in actual cases, the difference in the two formulations is not likely to produce much difference in results.

Finally, some might object to the proposed rule because it was drafted to apply to sexual abuse cases only, rather than to all tort cases or to all intentional tort cases. In this respect, the proposed rule may seem to reinscribe a version of sexual exceptionalism that this Article criticizes. I confess that having a separate rule to govern sexual abuse cases does run the risk of reinforcing the tendency to think about and treat sexual abuse as a species of conduct that is qualitatively different from other forms of violence and injurious conduct. However, as I hope this Article demonstrates, the objectionable feature of the sexual exceptionalism that pervades tort law comes not from treating sexual conduct differently per se, but from providing inadequate protection for victims of sexual abuse. I find nothing problematic in the view that sex abuse cases warrant a somewhat different approach given the variation in typical fact patterns. What is troubling is that sexual abuse cases have been treated as exceptional cases warranting an exception from the usual rule of vicarious liability. In other words, sexual exceptionalism has provided an "easy out" for courts to reject vicarious liability, without having to consider whether an enterprise "causes" sexual abuse and should fairly be held accountable to victims.

To reform tort law in the face of such resistance, courts need a rule that closely tracks the factual contexts of actual cases and is tailor-made for sex abuse and limited to sexual abuse cases. A more generally applicable rule that simply endorses "enterprise risk" or "enterprise causation," I fear, would not be potent enough to change the course of the law, as evidenced by the case law in California, which endorses the concept of enterprise risk yet rejects vicarious liability in most sexual 
abuse cases. ${ }^{349}$ Like so many other dilemmas of difference ${ }^{350}$ - where both denying difference and noticing difference has the potential to backfire - there is no sure way to guarantee that any particular change in the doctrine of vicarious liability will have the desired effect. This Article offers a proposal that notices the particularities of sexual abuse and is based on the recurring features of sexual abuse cases. It seems like the right strategy for U.S. courts to embrace today because it represents the most straightforward way to address and counter the sex exception to vicarious liability.

\section{CONCLUSION}

The sex exception to vicarious liability that U.S. courts have developed to restrict employer responsibility for sexual abuse committed by employees is somewhat of a puzzle. It has persisted despite a move in some jurisdictions to discard the traditional requirement that the offending employee possess a "motive to serve" the employer's interests in favor of more liberal tests centered on "enterprise risk." The exception has also persisted in the face of a more liberal posture taken by many courts in cases of non-sexual intentional violence, creating a double standard in the case law. ${ }^{351}$ Moreover, the exception finds little support in the mainstream academic torts literature, which largely embraces an "enterprise causation" approach to the imposition of vicarious liability and focuses on the ways that enterprises facilitate and produce recurring harms, drawing no distinction between sexual abuse and other types of intentional or negligently produced harms. 352

The resilience of a sex exception to legal liability is familiar, however, to feminist scholars who have long criticized exceptional treatment of

349 See supra text accompanying notes 67-81 (analyzing California's treatment of vicarious liability cases involving sexual misconduct).

350 See Chamallas, supra note 166, at 10-11 (discussing double binds and dilemmas of difference); MARTHA MINOW, MAKING ALL THE DifFERENCE: INCLUSION, EXCLUSION, AND AMERICAN LAW 20 (1990) (describing the phrase "dilemma of difference").

Decisions about... opportunities in society should not turn on an individual's ethnicity, disability, race, gender, religion, or membership in any other group about which some have deprecating or hostile attitudes. Yet refusing to acknowledge these differences may make them continue to matter in a world constructed with some groups, but

Id. not others, in mind.

351 See supra Part II.C (discussing the disparity in treatment between sexual and nonsexual violence).

352 See supra text accompanying notes 118-20 (explaining the enterprise causation theory of vicarious liability). 
sexual abuse in other contexts. ${ }^{353}$ Such resilience is also explainable by reference to common cognitive biases and ways of conceptualizing sex abuse in employment that place unwarranted emphasis on the internal traits of the individual offender, missing the significance of external, situational influences, most notably, the structural features and institutional culture of the enterprise. ${ }^{354}$

The proposed rule advanced in this Article to reform the law of vicarious liability is inspired by an analysis of a landmark decision of the Supreme Court of Canada, although I have shaped my proposal to fit the current landscape of U.S. tort law. I realize that any movement toward strict liability in the United States faces long odds in our tort system, which gravitates towards negligence and individual liability based on fault. But such a preference for negligence over strict liability cannot explain, nor justify, the decision to carve out a sex exception to employer vicarious liability for the tortious behavior of employees. Because sexual abuse committed by employees on the job is all too common, the law should not treat it as exceptional.

\footnotetext{
353 See supra text accompanying notes 166-77 (describing feminist-inspired reforms of doctrines that imposed heightened proof requirements in rape cases).

354 See supra Part IV.B (discussing insights from cognitive psychology and their application to sexual abuse cases).
} 
